\title{
$\mathrm{RCP}$ 시나리오 하에서 전망된 강원도 관광 기후자원의 미래 변화
}

\author{
임창묵 1 정일웅 2 \\ ${ }^{1} \mathrm{APEC}$ 기후센터, ${ }^{2}$ 강릉원주대학교 대기환경과학과
}

(2015년 6월 1일 접수, 2015년 6월 29일 수정, 2015년 6월 29일 게재 확정)

\section{Future Changes of the Tourism Climate Resources in Gangwon-do Projected under the RCP Scenarios}

\author{
Chang-Mook $\mathrm{Lim}^{1} \cdot$ Il-Ung Chung ${ }^{2}$ \\ ${ }^{1}$ APEC Climate Center \\ ${ }^{2}$ Department of Atmospheric and Environmental Sciences, Gangneung-Wonju National University \\ (Received 1 June 2015, Revised 29 June 2015, Accepted 29 June 2015)
}

\begin{abstract}
In this study, we tried to assess the future projection of the climate as a tourism resource in Gangwon region based on Tourism Climatic Index (TCI) and two RCP scenarios(RCP4.5 and RCP8.5) datasets. TCI combines five climatic aspects relevant for outdoor tourism activity: daytime comfort(CID), average (or daily) comfort(CIA), sunshine(S), precipitation(P) and wind(W). The mean annual variation of TCI at most of stations shows bi-modal peak pattern, but the variation at Daegwallyeong shows unique summer peak pattern. During the 21st century, TCI in summer has distinct declining trend, and this tends to be more rapid in higher emission scenario(RCP8.5) than in lower emission scenario(RCP4.5). We found Daegwallyeong is expected to experience the most distinguished change in the late 21st century as annual variation pattern of TCI is likely to shift from summer peak to bi-modal peaks. Spatial distribution of the future TCI shows that maximum changes are likey to occur along high mountains(Backdudaegan), and summertime(June to September) climate conditions for tourism activities are expected to be increasingly deteriorated, while wintertime conditions are expected to be preferable more or less. It notes that magnitude of the change in RCP8.5 scenario estimates 2-3 times larger than in RCP4.5 scenario. To identify causes of the long-term TCI trends, we analyzed the contribution level of each sub-index to the trends. Consequently, it reveals that the most primary contributor is CID. However, CIA, P, and S also can highly contribute in some cases.
\end{abstract}

Key Words : climate change, climate resources, tourism, tourism climatic index(TCI)

주요어 : 기후변화, 기후자원, 관광, 관광기후지수(TCI)

Correspondence: Il-Ung Chung, Department of Atmospheric and Environmental Sciences, Gangneung-Wonju National University, 7, Jukheon-gil, Gangneung, Gangwon, 210-702, Republic of Korea, Phone: +82-33-640-2325, Fax: +82-33-640-2320, E-mail: iuchung@gwnu.ac.kr 


\section{1. 서론}

기후는 야외 관광 활동에 영향을 미치는 중요한 관광 자원 중 하나이며, 관광객들의 관광 활동 여 부와 관광지 선택을 결정짓는 주요 요소이다. 기 후변화는 직접적으로 관광자원의 변화를 초래하 며, 간접적으로 자연환경의 변화, 사회경제적 변 화, 그리고 정책 변화를 유발시켜 관광객의 선호 와 흐름의 변화를 일으킨다(MCST, 2009). 관광 활동에 미치는 기후변화의 영향은 긍정적인 측면 과 부정적인 측면을 동시에 가지고 있다. 긍정적 인 측면의 예로서, 기후변화로 인해 특정 기후환 경에서만 자라는 과일, 꽃, 채소 등의 수확이 가능 해짐에 따라 이를 관광자원으로 활용하여 관광객 들의 관광 활동을 유도하는 경우를 들 수 있다. 하 지만 기후변화가 관광 활동에 미치는 영향은 긍정 적인 측면보다는 부정적인 측면이 더욱 지배적이 다. 눈을 주요 관광 기후자원으로 하는 스키장의 경우, 온난화로 인해 제설(snowmaking) 비용이 증 가하고 제설 가능 일수가 줄어들면서 스키장 개장 시즌이 단축되는 등의 경영 여건의 악화를 야기시 키고, 해수면 상승으로 인한 모래사장의 손실, 태 풍 혹은 폭우로 인한 관광시설 및 자연환경의 훼손 등이 점점 증가한다(UNWTO and UNEP, 2008). 그럼에도 불구하고 미래 기후변화에 따른 기온 상 승, 해수면 상승, 기상재해 빈발 등의 이상 기후 현상이 관광산업에 미치는 영향과 취약성에 대한 과학적인 평가가 국내에서는 아직 체계적으로 연 구되지 않았다. $\operatorname{Kim}(2008)$ 은 관광산업과 기후변 화의 관계를 원인자(vector)와 피해자(victim)으로 정의하고, 기후변화 대응체계로써 관광과 기후변 화의 관련성에 대한 정부, 업계, 일반 관광객들의 인식을 증진시키고 관광과 기후변화의 상호영향에 대한 체계적 모니터링과 과학적 조사연구, 탄소중 립 관광(단)지 조성 시범사업의 추진, 관광업계의
기후변화 대응 지원 프로그램 시행, 탄소상쇄프로 그램의 도입, 관광부문의 기후변화 대응 실행계획 의 수립이 필요하다고 제안하였다.

IPCC 5차 평가보고서(IPCC, 2013)에 따르면, 온실가스 농도의 증가에 의한 온난화로 지난 133 년(1880-2012) 동안 전지구 평균기온이 $0.85 \pm$ $0.21^{\circ} \mathrm{C}$ 상승하였고, 해수면은 1901 년 이후 $19 \mathrm{~cm}$ 가 상승한 것으로 나타났다. 현재 수준의 온실가 스 배출이 지속된다면(고배출 시나리오) 21 세기 후 반의 전지구 평균기온은 현재 대비 $3.7^{\circ} \mathrm{C}$ 증가하 고, 해수면은 $63 \mathrm{~cm}$ 상승할 것으로 전망된다고 보 고하였다. 반면 온실가스의 감축 노력이 이루어 지면(저배출 시나리오) 전지구 평균기온은 $1.8^{\circ} \mathrm{C}$, 해수면은 $47 \mathrm{~cm}$ 가 상승하며 상승 추세를 완화할 수 있을 것으로 전망하였다. 최근 기상청 산하 국 립기상과학원이 발간한 전지구 기후변화 보고서 (NIMR, 2012)에서는 고배출 시나리오 하에서 21 세기 후반(2076-2100)에 대해 전망된 우리나라의 연평균 기온은 현재(1981-2005) 대비 $4.9^{\circ} \mathrm{C}$ 상승 하는 것으로 나타났다.

기후변화가 미치는 한 관광지의 취약성을 판단 하기 위해서는 정량적인 척도가 필요하다. de Frei$\operatorname{tas}(2003)$ 에 따르면, 1960년대 이후부터 관광산업 에 “이로운 기후(favourable climate)"에 관한 여러 척도들이 많이 개발·응용되어 왔다. 이 척도들 가 운데 Mieczkowski(1985)에 의해 개발된 관광기후 지수(tourism climatic index, 이하 TCI)는 야외 관 광 - 레저 활동에 직접적으로 영향을 주는 7 개의 기 후 요소들을 조합하여 단일 지수로 표현한 지수 로서 포괄적이면서도 계산이 비교적 간단한 장점 이 있어 기후변화에 따른 관광 기후자원의 변화를 분석하기 위한 많은 연구들에 활용되었다. Scott et al. (2004)은 북미 지역에서의 TCI의 현황과 미 래 전망을 분석하였고, 나아가 Scott et al.(2008) 은 캐나다, 뉴질랜드, 스웨덴을 대상으로 도시, 해 
변, 산악지역의 TCI 수치에 기후인자가 미치는 영 향 정도를 분석하였다. 또한, Amelung and Viner (2006)는 지중해 지역 TCI의 미래 변화 전망을 보였으며, Amelung et al.(2007)은 전지구적 규모 에서 $\mathrm{TCI}$ 를 응용하였다. TCI는 주관성 및 검증 이 부족하여 심각한 한계를 갖고 있다는 비판을 받기도 하였다(de Freitas et al., 2008; Scott et al., 2008). Perch-Nielsen et al.(2010)은 일 TCI를 산출 할 수 있도록 계산 과정을 개선시킴으로써 유럽 지 역을 대상으로 SRES(Special Report on Emission Scenarios) A2 시나리오 하에서 미래 TCI 변화의 공간분포 특징을 제시하였다.

관광산업에 미치는 기후변화의 영향에 관한 국 외 연구는 활발한데 비해 국내 연구는 최근에 들어 서 활기를 띠는 모습이다. Heo and Lee(2008a,b; 2010)는 기후변화가 용평 스키장을 사례로 우리 나라 스키산업에 미치는 영향을 평가하였고, $\mathrm{Heo}$ and Lee(2012)는 SRES A1B 시나리오 자료를 사용 하여 우리나라 지역별 스키 산업의 미래 전망에 대 해 분석하였다. 그러나 $\mathrm{TCI}$ 와 같은 종합적 지수를 활용한 관광 기후자원의 변화 연구는 거의 이루어 지지 않다. $\mathrm{Cho}(2009)$ 는 겨울철 관광산업에 미치 는 기후변화의 영향에 관한 연구를 수행한 바 있으 나 국외 연구 동향 조사의 일환으로 $\mathrm{TCI}$ 를 소개하 는 수준에 머무르고 있다. 최근에 와서야 기후변 화와 관광산업의 연관성에 관한 연구의 필요성이 제기되면서 Chung et al. (2013)은 TCI를 활용하여 강원도 지역을 대상으로 기후변화에 따른 관광 기 후자원의 장기 변화 추세를 조사하고 그 원인 파악 을 시도하였다. 보다 더 최근에 Park et al.(2014)은 $\mathrm{TCI}$ 를 이용하여 치악산 국립공원의 관광기후환경 의 변화 현황과 미래 전망을 분석하였다.

강원도는 GRDP에서 관광산업의 비중이 $20 \%$ 이상으로서 제주도 다음으로 관광산업에 대한 의 존도가 높으며, 지역 관광산업의 주된 자원이 천
혜의 자연환경 및 지역 특산물인 만큼 미래 기후 관광자원의 미래 변화를 전망하는 것은 과학적 차 원을 넘어 사회경제적으로도 지대한 중요성을 가 진다. 이에, TCI에 기반하여 강원도 지역에서의 관광 기후자원의 미래 변화를 분석하고 그 추세 를 정량적으로 평가하고자 한다. 아울러 $\mathrm{TCI}$ 의 미 래 변화에 영향을 미치는 기후 인자를 분석함으로 써 관광 기후자원 변화 추세의 원인을 밝히고자 한 다.

\section{2. 연구 방법 및 자료}

\section{1) 연구 방법}

$\mathrm{TCI}$ 는 야외 관광 및 레저 활동을 쾌적하게 즐 길 수 있는 사람의 일반적인 생태학적 조건에 기 초를 두고 Mieczkowski(1985)가 최초로 개발한 지 수로서 7 가지 기후 요소들(일평균기온, 일 최고기 온, 일평균상대습도, 일 최저상대습도, 강수량, 일 조시간, 일평균풍속)을 평가한다. $\mathrm{TCI}$ 는 하부지 수(sub-index)인 5가지 기후 지수들-낮 쾌적지수 (daytime comfort index) CID, 일 쾌적지수(daily comfort index) $C I A$, 강수량 지수 $P$, 일조시간 지 수 $S$, 그리고 풍속 지수 W-을 종합화함으로써 다 음 식과 같이 산출된다:

$$
T C I=2[(4 \times C I D)+C I A+(2 \times P)+(2 \times S)+W]
$$

이 하부지수들은 Table 1과 같이 Amelung et al. (2007)의 배점 체계(rating system)에 따라 각 기후 요소들을 평가하여 최대 5점에서 최소 -3점을 배 점하며, 각 하부지수에 곱해진 숫자는 $\mathrm{TCI}$ 에 대한 가중치를 의미한다. 즉, $\mathrm{TCI}$ 에 대해 $C I D$ 는 $40 \%$, $\mathrm{P}$ 와 $\mathrm{S}$ 는 각각 $20 \%, C I A$ 와 $W$ 는 각각 $10 \%$ 의 가중 치를 갖는다. 관광하기에 가장 쾌적한 기후조건인 
Table 1. Rating system for the sub-indices of tourism climatic index (modified Amelung et al., 2007).

\begin{tabular}{|c|c|c|c|c|c|c|c|}
\hline \multirow{3}{*}{ Score } & \multirow{3}{*}{$\begin{array}{c}\text { CID/CIA } \\
\text { Apparent } \\
\text { Temperature } \\
\left({ }^{\circ} \mathrm{C}\right)\end{array}$} & \multirow{3}{*}{$\begin{array}{c}\text { P } \\
\text { Precipitation } \\
(\mathrm{mm} / \mathrm{month})\end{array}$} & \multirow{3}{*}{$\begin{array}{c}S \\
\text { Sunshine } \\
\text { duation } \\
\text { (hours/day) }\end{array}$} & \multicolumn{4}{|c|}{ W } \\
\hline & & & & Normal & Trade & Hot & Cold \\
\hline & & & & \multicolumn{3}{|c|}{ Wind speed $(\mathrm{km} / \mathrm{hr})$} & $\operatorname{WCT}\left({ }^{\circ} \mathrm{C}\right)$ \\
\hline 5.0 & $20 \sim 27$ & $0.0 \sim 14.9$ & $>10$ & $\langle 2.88$ & $12.24 \sim 19.79$ & & \\
\hline 4.5 & $\begin{array}{l}19 \sim 20 \\
27 \sim 28\end{array}$ & $15.0 \sim 29.9$ & $9 \sim 10$ & $2.88 \sim 5.75$ & & & \\
\hline 4.0 & $\begin{array}{l}18 \sim 19 \\
28 \sim 29\end{array}$ & $30.0 \sim 44.9$ & $8 \sim 9$ & $5.76 \sim 9.03$ & $\begin{array}{c}9.04 \sim 12.23 \\
19.80 \sim 24.29\end{array}$ & & \\
\hline 3.5 & $17 \sim 18$ & $45.0 \sim 59.9$ & $7 \sim 8$ & $9.04 \sim 12.23$ & & & \\
\hline 3.0 & $15 \sim 17$ & $60.0 \sim 74.9$ & $6 \sim 7$ & $12.24 \sim 19.79$ & $\begin{array}{c}5.76 \sim 9.03 \\
24.30 \sim 28.79\end{array}$ & & \\
\hline 2.5 & $10 \sim 15$ & $75.0 \sim 89.9$ & $5 \sim 6$ & $19.80 \sim 24.29$ & $2.88 \sim 5.75$ & & \\
\hline 2.0 & $5 \sim 10$ & $90.0 \sim 104.9$ & $4 \sim 5$ & $24.30 \sim 28.79$ & $\begin{array}{c}\langle 2.88 \\
28.80 \sim 38.52\end{array}$ & $<2.88$ & \\
\hline 1.5 & $0 \sim 5$ & $105.0 \sim 119.9$ & $3 \sim 4$ & $24.30 \sim 28.79$ & & $2.88 \sim 5.75$ & \\
\hline 1.0 & $-5 \sim 0$ & $120.0 \sim 134.9$ & $2 \sim 3$ & $28.80 \sim 38.52$ & & $5.76 \sim 9.03$ & $>-2$ \\
\hline 0.5 & & $135.0 \sim 149.9$ & $1 \sim 2$ & & & $9.04 \sim 12.23$ & $-11 \sim-2$ \\
\hline 0.25 & & & & & & & \\
\hline 0.0 & $-10 \sim-5$ & $>150.0$ & $<1$ & $>38.52$ & $>38.52$ & $>12.24$ & $\leq 11$ \\
\hline-1.0 & $-15 \sim-10$ & & & & & & \\
\hline-2.0 & $-20 \sim-15$ & & & & & & \\
\hline-3.0 & $<-20$ & & & & & & \\
\hline
\end{tabular}

경우 5 개 하부지수들은 각각 5 점을 부여받아 $\mathrm{TCI}$ 가 100 점 만점이 되며, 최악의 경우 -30 점이 된 다. 이렇게 산출된 TCI는 Mieczkowski(1985)가 제 시한 관광 활동 적합도 평가표(Table 2)에 의해 해 당 지역에서의 관광 활동의 적합성 및 쾌적성을 평 가할 수 있다.

$C I D$ 와 $C I A$ 는 열적 쾌적도로서 전통적으로는 기온과 상대습도의 함수인 유효온도(effective temperature, ET)에 근거하여 산출되었으나, $E T$ 보다 체감온도(apparent temperature, $A T)$ 를 사용하는 것이 더 적절하다고 주장한 최근 Scott et al.(2004) 과 Perch-Nielsen et al. (2010)의 주장을 받아들여 이 연구에서는 $C I D$ 와 $C I A$ 를 계산하기 위해 다음 식
Table 2. Rating categories of the tourism climatic index (Mieckzowski, 1985).

\begin{tabular}{c|c}
\hline \hline Range of TCI score & Condition \\
\hline $90-100$ & Ideal \\
$80-89$ & Excellent \\
\hline $70-79$ & Very good \\
$60-69$ & Good \\
\hline $50-59$ & Acceptable \\
$40-49$ & Marginal \\
\hline $30-39$ & Unfavourable \\
$20-29$ & Very unfavourable \\
$10-19$ & Extremely unfavourable \\
$<10$ & Impossible \\
\hline \hline
\end{tabular}


으로 주어지는 AT를 사용하였다:

$$
A T=-1.3+0.92 \times T+2.2 \times e
$$

이 식은 Steadman(1984)에 의해 고안된 경험식 으로서 기온 $T\left({ }^{\circ} \mathrm{C}\right)$ 와 수증기압 $e(\mathrm{kPa})$ 에 의해 $A T$ 가 계산된다. $C I D$ 를 산출하기 위해서는 최고기 온, $C I A$ 를 산출하기 위해서는 평균기온을 $T$ 값으 로 사용한다.

W는 Perch-Nielsen et al.(2010)에 따라 Table 3과 같이 평균기온 $(T)$ 과 평균풍속 $(V)$ 에 대해 4가지 상 태로 구분한다. 여기서 $T$ 와 $V$ 의 단위는 각각 ${ }^{\circ} \mathrm{C}$, $\mathrm{km} / \mathrm{hr}$ 이다. 단, 추움(cold) 상태인 경우 풍속을 대 신하여 Osczevski and Bluestein(2005)이 고안한 풍속냉각 상당온도(wind chill equivalent temperature, WCT)를 평가하게 되는데, 이 WCT는 우리 나라 기상청에서 제공하는 겨울철 체감온도와 같 다:

$$
\begin{aligned}
W C T= & 13.12+0.6215 T-11.35 V^{0.16} \\
& +0.3965 T V^{0.16}
\end{aligned}
$$

월별 TCI를 얻기 위해 7 개 기후 요소의 월 평 균값(단, 강수량은 월 누적값)들을 사용하여 TCI 를 산출하였으며, 상세 분석은 영서지역, 영동지 역, 고산지역을 대표할 수 있는 몇몇 지점을 선택 하여 이루어졌다. 이렇게 산출된 TCI에 대해 먼

Table 3. Condition table for $W$ (Perch-Nielsen et al., 2010).

\begin{tabular}{c|c}
\hline \hline Category & Condition \\
\hline Normal & $5^{\circ} \mathrm{C} \leqq \mathrm{T}<24^{\circ} \mathrm{C}$ \\
Trade & or $\mathrm{T}<5^{\circ} \mathrm{C}, \mathrm{V}<5 \mathrm{~km} / \mathrm{h}$ \\
Hot & $24^{\circ} \mathrm{C} \leqq \mathrm{T}<33^{\circ} \mathrm{C}$ \\
Cold & $\mathrm{T} \geqq 33^{\circ} \mathrm{C}$ \\
\hline \hline
\end{tabular}

저 평균 연변화를 분석하였다. TCI의 평균 연변화 는 지역마다 유형의 특징이 각기 다르게 나타나는 데, Scott et al.(2004)은 이러한 TCI의 연변화 유 형의 특징을 6개 유형-최적형(optimal), 어려움 형(poor), 여름피크형(summer peak), 겨울피크형 (winter peak), 양봉피크형(bi-modal peak), 그리고 건기피크형(dry season peak)-으로 나누었다. 평 균 연변화와 더불어 장기변화 추세를 분석하여 계 절적 특징과 미래 전망을 살펴보았으며, 21세기 초반과 후반에서의 $\mathrm{TCI}$ 의 공간 분포를 분석하여 지역적 특징과 그 변화를 전망하였다. 또한 $\mathrm{TCI}$ 의 미래 변화에 대한 추세를 이해하기 위해 어떤 기후 인자의 영향이 지배적인 파악하는 원인분석을 수 행하였다. 그 방법으로는 $\mathrm{TCI}$ 를 이루는 각 하부지 수들의 추세를 분석하여 그 기여도를 분석하는 것 으로 다음의 식을 통해 기여도를 산출할 수 있다:

$$
X_{\text {cont }}=\frac{X_{w} \times X_{a}}{4 C I D_{a}+C I A_{a}+2 P_{a}+2 S_{a}+W_{a}} \times 100
$$

여기서 $\mathrm{X}_{\mathrm{cont}}$ 는 파악하고자 하는 하부지수 $(X)$ 의 기여도를 의미하며, 첨자 $\mathrm{a}$ 는 각 하부지수의 변화 추세에 대한 기울기, 각 하부지수에 곱해진 숫자 는 식 (1)에서 제시된 TCI에 대한 가중치를 의미 한다. $\mathrm{X}_{\mathrm{w}}$ 는 파악하고자 하는 하부지수 $(\mathrm{X})$ 의 가중 치를 의미하며, $C I D$ 의 기여도를 파악하고자 할 경 우 $\mathrm{X}_{\mathrm{w}}$ 는 4 가 되고 $C I A$ 의 기여도를 파악하고자 할 경우 $\mathrm{X}_{\mathrm{w}}$ 는 1 이 되는 식이다. 단, 각 항들이 전부 0 일 경우와 $\mathrm{TCI}$ 의 추세가 0 일 경우에 기여도 분석 이 무의미하다. 하부지수의 추세가 TCI의 추세와 같은 방향의 부호를 갖는 경우 순기여도, $\mathrm{TCI}$ 의 추세와 반대 부호를 갖는 경우 역기여도가 나타나 며, 역기여의 경우 하부지수의 영향이 TCI의 추세 를 줄이는 데 기여함을 의미한다. 


\section{2) 자료}

계산된 $\mathrm{TCI}$ 를 분석하기 위해 강원도 영동 지역 을 대표하는 강릉, 영서 지역을 대표하는 춘천과 원주, 고산지형을 대표하는 대관령을 대상으로 가 용한 관측 기간 동안의 일평균 기상 자료와 RCP 시나리오 2종(RCP4.5 및 RCP8.5) 하에서 전망 된 한반도 전망자료(HadGEM3-RA)를 사용하였 다. 관측 자료의 기간은 Table 4와 같이 각 지점별 관측 개시년도로부터 2010년까지이며, TCI의 월 별 평년값을 분석하기 위해 1971-2000년 기간에 대한 평균값을 분석하였다. 단, 관측 개시년도가 1971년 이후인 지점에 대해서는 관측 개시년도로 부터 30 년을 평년 기간으로 삼았다. 한반도 전망 자료는 한반도 영역에 대해 $12.5 \mathrm{~km}$ 의 공간 해상 도를 가지며, 2011-2100년의 90년 기간에 대한 일 자료를 분석하였다. 미래 TCI의 월별 평년값에 대 해서는 2071-2100년 기간의 30년 평균값을 사용 하였다. 분석 요소는 일평균기온, 일 최고기온, 일 평균상대습도, 일 최저상대습도, 일평균운량, 일 강수량, 일평균일조시간, 그리고 풍속 등 8 개 요소 이다. 여기서, 한반도 전망자료는 일조시간을 제 공하지 않기 때문에 Lim and Chung(2013)에 의해 개발된 운량 정보 기반 일조시간 산출 방법에 따른 일조시간을 처방하였다. 단, $\mathrm{TCI}$ 의 공간분포 분 석에는 자료 가용의 한계로 인해 Scott $e t$ al. (2004) 이 사용한 방법을 따라 관측된 일조시간의 월별 평 년값을 처방하였다. 간접적으로 얻은 일조시간으
로부터 산출된 $\mathrm{TCI}$ 의 해석에 각별한 주의가 필요 하며, 보다 정확한 미래 $\mathrm{TCI}$ 를 분석하기 위해 더 많은 연구가 필요한 단계이다. 한반도 전망자료의 지점별 $\mathrm{TCI}$ 의 분석은 해당 지점의 위·경도 정보 로부터 통계적 내삽 방법을 이용하여 지점 값을 추 출하여 수행하였다.

\section{3. 결과}

\section{1) $\mathrm{TCl}$ 의 평균 연변화}

$\mathrm{TCI}$ 의 미래 변화 추세를 분석하기에 앞서 먼저 평균 연변화를 분석하였다. Figure 1 은 영서지역 인 원주와 춘천, 영동지역인 강릉, 그리고 고산지 역인 대관령의 4 개 지점에 대하여 관측(a)된 $\mathrm{TCI}$ 의 연변화와 $\mathrm{RCP} 4.5(\mathrm{~b})$ 및 $\mathrm{RCP} 8.5(\mathrm{c})$ 시나리오 하 에서 전망된 21세기 후반(2071-2100년) TCI의 연 변화를 나타낸 것이다. 관측된 원주, 춘천, 그리 고 강릉 지역의 $\mathrm{TCI}$ 는 대체로 $40 \sim 80$ 의 범위에 서 연변화를 보이며, 봄(5월)과 가을(9월)에 최대 를 보이고 여름(7-8월)과 겨울(12-1월) 최소를 보 인다. 반면에, 관측된 대관령 지역의 $\mathrm{TCI}$ 의 연변 화는 여름(6-8월)에 최대가 나타나고 겨울(12-2 월)에 최소가 나타나면서 타 지역과 차별적인 모습 을 보인다. Scott $e t a l$.(2004)의 TCI 연변화 유형 구분법에 따르면, 원주, 춘천, 강릉의 $\mathrm{TCI}$ 의 연변 화 유형은 양봉피크형에 해당하며, 대관령의 TCI

Table 4. List of the observation stations in Gangwon region selected for this study.

\begin{tabular}{c|c|c|c|c}
\hline \hline Station & Location & $\begin{array}{c}\text { Beginning of } \\
\text { observation }\end{array}$ & $\begin{array}{c}\text { Observation period } \\
\text { (years) }\end{array}$ & Normal period \\
\hline Wonju & $37^{\circ} 20^{\prime} \mathrm{N}, 127^{\circ} 56^{\prime} \mathrm{E}$ & 1973 & 38 & $1973-2002$ \\
Chuncheon & $37^{\circ} 54^{\prime} \mathrm{N}, 127^{\circ} 44^{\prime} \mathrm{E}$ & 1966 & 45 & $1971-2000$ \\
Daegwallyeong & $37^{\circ} 40^{\prime} \mathrm{N}, 128^{\circ} 43^{\prime} \mathrm{E}$ & 1972 & 39 & $1972-2001$ \\
Gangneung & $37^{\circ} 45^{\prime} \mathrm{N}, 128^{\circ} 53^{\prime} \mathrm{E}$ & 1912 & 99 & $1971-2000$ \\
\hline \hline
\end{tabular}



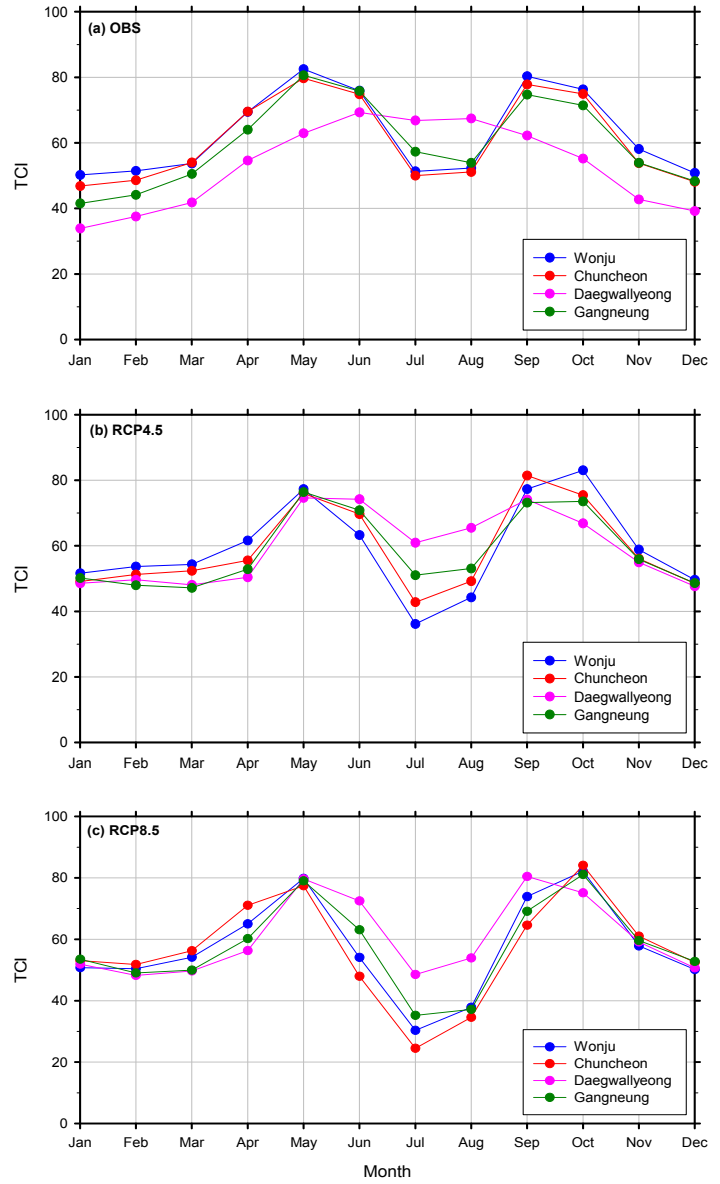

Figure 1. Mean annual cycles of $\mathrm{TCl}$ at Wonju, Chuncheon, Daegwallyeong, and Gangneung.

(a) Observation, (b) RCP4.5, (c) RCP8.5.

의 연변화 유형은 여름피크형에 해당된다. 21세 기 후반의 강릉, 원주, 춘천 지역의 TCI 연변화는 관측과 동일한 양봉피크형으로 유형의 변화는 나 타나지 않지만 여름철의 감소가 나타나면서 유형 의 크기에 변화를 보였다. 특히 RCP4.5 시나리오 보다 RCP8.5 시나리오에서 뚜렷한 변화를 보이는 데, RCP8.5 시나리오에서 전망된 세 지점의 여름 철(7-8월) TCI는 모두 40 이하로 Table 2의 카테 고리 분류에 따라 '나뽐(Unfavourable)'의 상태까 지 쾌적도가 하락하였다. 이러한 TCI의 미래 변화 는 대관령의 연변화 유형 변화에도 큰 영향을 미
친다. $\mathrm{RCP} 4.5$ 시나리오 하에서 전망된 대관령의 $\mathrm{TCI}$ 는 여름철을 제외한 나머지 계절에서 크게 증 가하여 상대적으로 여름철 TCI가 주변의 봄철 및 가을철보다 작게 나타나면서 양봉피크형의 연변화 유형으로 변화하였다. RCP8.5 시나리오에서는 대 관령의 여름철 TCI가 큰 폭으로 감소하면서 더욱 두드러진 양봉피크형의 유형을 보이고 있다. 이는 미래의 대관령은 관광 활동에 있어 여름철 고산지 대의 기후 특징이 사라지고 영동.영서 지역의 기 후대로 변화함을 시사한다.

\section{2) 월별 $\mathrm{TCl}$ 의 공간적 패턴 변화 전망}

강원지역 미래 TCI의 공간적인 분포의 특징을 살펴보기 위해 RCP4.5 및 RCP8.5 시나리오 하에 서 전망된 21세기 초반 10년(2011-2020년)과 21세 기 후반 10년(2091-2100년) 월 평균 TCI의 공간 분포도를 분석하였다. 또한, 21 세기 후반과 초반 의 TCI의 차이를 통해 TCI의 공간 분포의 미래 변 화를 살펴보았다. Figure 2는 RCP4.5 시나리오 하 에서 전망된 $\mathrm{TCI}$ 의 21 세기 초반 10 년 월 평균 공 간분포도이다. 겨울철에 해당하는 12 월, 1 월, 2 월 의 $\mathrm{TCI}$ 는 태백산맥을 중심으로 최소가 나타나며, 특히 1월에 '매우 나쁨(20-29)'으로 가장 낮게 나 타난다. 3월로 갈수록 $\mathrm{TCI}$ 는 전 지역에 걸쳐 '좋 지도 나쁘지도 않음(40-49)'의 상태까지 점차 증 가하지만 태백산맥 중심에서 TCI가 최소가 나타 나는 현상은 동일하다. 4 월의 $\mathrm{TCI}$ 는 대부분 지역 에서 '괜찮음(50-59)' 상태를 보이고 영서지역보 다 태맥산맥의 산악지역을 포함한 영동 지역에서 조금 더 낮게 나타나는 것이 특징이다. 5월의 TCI 는 여전히 태백산맥 중심에서 최소가 나타나긴 하 지만 전체적으로 '좋음(60-69)' 이상을 보이고 특 히 영서 지역은 '매우 좋음(70-79)'으로 타 지역보 다 쾌적도가 높게 나타난다. 6월의 TCI는 영서 지 역의 일부 서쪽 지역에서 5월보다 다소 작게 나타 

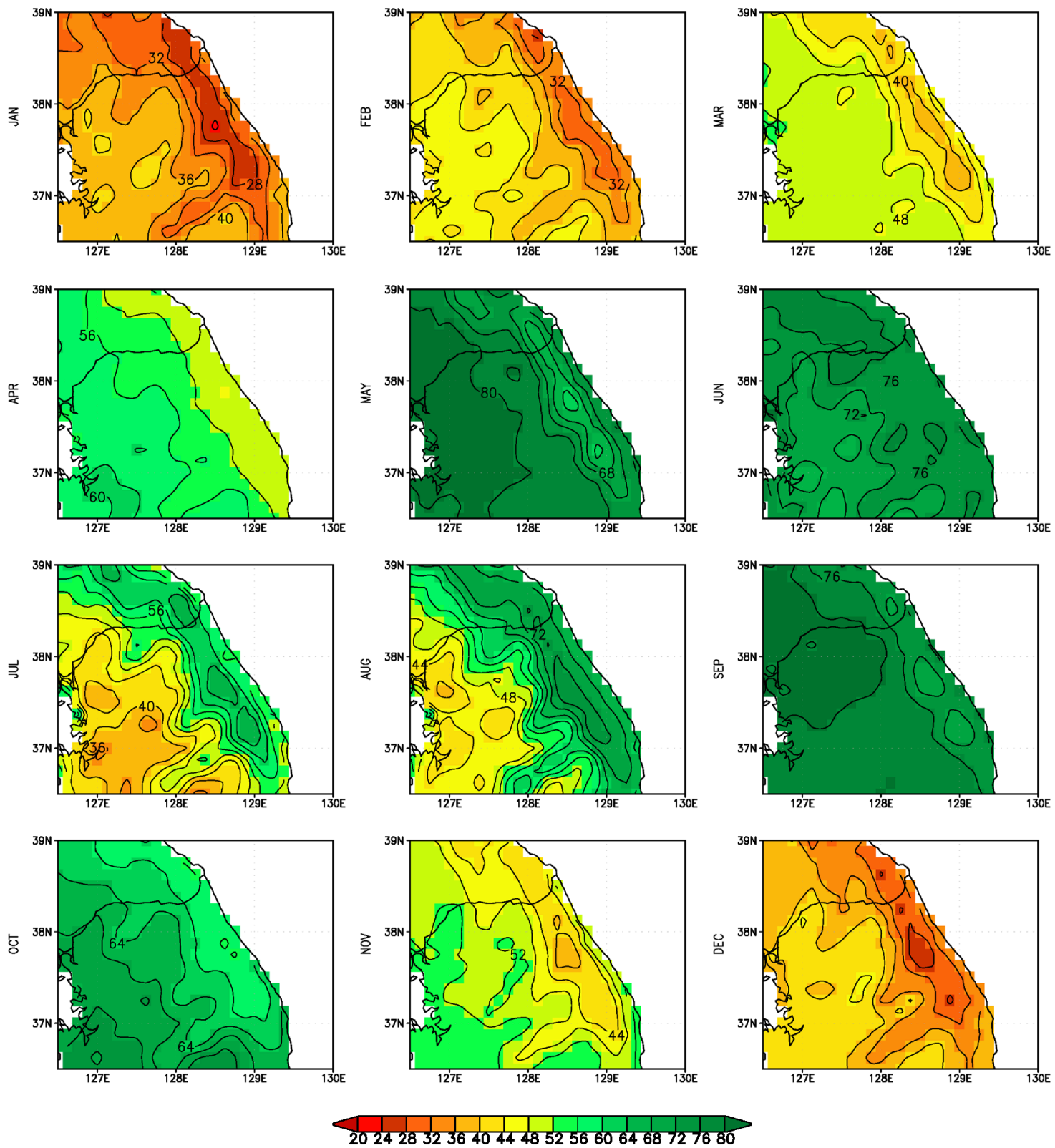

Figure 2. Projected distribution of monthly TCl for the first decade(2011-2020) of the 21st century in Gangwon region under the RCP4.5 scenario.

나지만 태백산맥의 산악지역을 포함한 대부분의 지역에서 '매우 좋음'을 보이면서 대체로 관광하기 쾌적한 상태를 나타내고 있다. 7월부터 TCI는 다 시 감소하여 영서 지역을 중심으로 가장 크게 감
소하는 것으로 전망되었다. 그리고 태백산맥에서 $\mathrm{TCI}$ 의 최소를 보였던 다른 계절과 달리 '좋음' 범 위의 최대가 나타난다. 8월의 TCI 또한 태백 산맥 을 중심으로 최대가 나타나며 7월보다 더 높은 값 

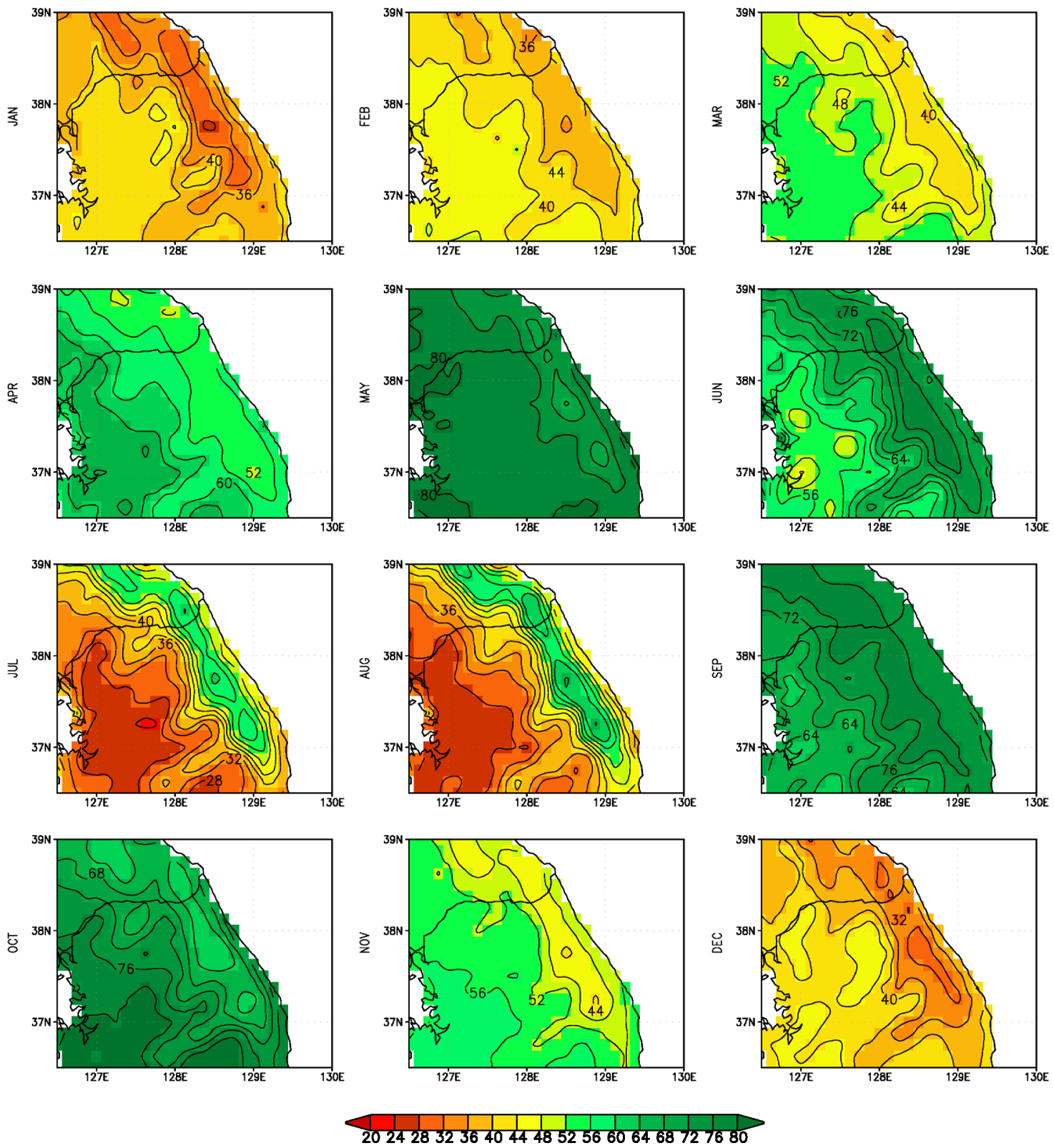

Figure 3. Same as Figure 2 except for the last decade(2091-2100).

을 보이고 있다. 가을이 시작되는 9월의 TCI는 6 월과 마찬가지로 강원도 전체 지역에 대해서 관광 하기 쾌적한 상태로 전망되었다. 그러한 상태는 10 월까지 지속되다가 11 월부터 태백산맥을 중심 으로 다시 TCI가 감소하는 것으로 나타났다. 즉,
$\mathrm{RCP} 4.5$ 시나리오에서 전망된 21세기 초반의 관광 활동의 쾌적도는 겨울철 태백산맥을 중심으로 가 장 낮게 나타나고, 5월과 6월, 9월, 그리고 10월에 강원도 지역 대체로 쾌적한 상태로 전망되었다.

Figure 3은 RCP4.5 시나리오 하에서 전망된 
$\mathrm{TCI}$ 의 21 세기 후반 10 년 월 평균 공간분포도를 나 타낸 그림이다. 겨울철에 해당하는 1 월과 2 월, 그 리고 12 월의 $\mathrm{TCI}$ 는 태백산맥의 중심에서 최소가 나타나는 21 세기 초반 10 년 월 평균된 TCI과 동일 한 지역적 특징을 보이고 있다. 21 세기 후반 1 월의 TCI는 태백산맥 중심에서 약 30-36(나쁨)을 보이 면서 21세기 초반 약 24-28(매우 나쁨)을 보인 것 에 비해 다소 높아진 것을 확인할 수 있다. 2월의 TCI 또한 21세기 초반에 비해 21세기 후반에 높 게 전망되었다. 3 월의 $\mathrm{TCI}$ 는 강원 지역 대부분 '좋 지도 나쁘지도 않음'을 보이고 영서 지역의 일부에 서 '괜찮음'을 보이기도 한다. 4 월의 TCI는 3 월의 $\mathrm{TCI}$ 보다 10 정도 증가하여 대부분 지역에서 '관찮 음'이 나타난다. 5월부터는 태백산맥 중심 지역의 일부를 제외한 나머지 지역에서 관광하기 '매우 좋 음 상태를 보인다. 여름이 시작되는 6월의 TCI는 5월에 비해 태백산맥 중심 지역의 $\mathrm{TCI}$ 는 다소 증 가하고, 영동 지역과 영서 지역은 감소하는 것으 로 나타나며, 특히 영서 지역이 영동 지역보다 비 해 감소가 뚜렷하게 나타난다. 7월과 8월의 TCI는 6월에 비해 뚜렷하게 작은 값을 보이나, 태백산맥 중심 지역으로 갈수록 $\mathrm{TCI}$ 는 크게 높아지며 최대 를 보이고 있다. 가을철인 9월부터 전 지역에 걸쳐 $\mathrm{TCI}$ 가 '매우 좋음'으로 단계가 상승하지만 10 월부 터 태백산맥을 중심으로 서서히 다시 감소하여 12 월까지 계속된다. 즉, 21 세기 후반의 TCI는 21 세 기 초반에 비해 태백산맥을 중심에서 더욱 뚜렷한 지역적 특징을 보이며, 7월과 8월을 비롯한 6월에 서도 태백산맥 중심 지역이 다른 지역에 비해 뚜렷 하게 높은 값을 보인다. 21 세기 초반과 같이 5 월과 6월, 9월 그리고 10 월에 비교적 관광하기 쾌적하 고, 겨울철과 여름철에 관광하기 불쾌한 기후 조 건이 나타나는 것으로 전망되었다. RCP4.5 시나 리오 하에서 전망된 21 세기 강원 지역 $\mathrm{TCI}$ 의 미래 분포 변화를 살펴보기 위해 Figure 4와 같이 21세
기 후반 10 년과 21 세기 초반 10 년의 차이를 분석하 였다. 1-4월의 TCI는 21세기 후반으로 갈수록 영 서 지역의 일부에서 약한 감소를 보이기도 하지만 전반적으로 약한 증가를 보인다. 5월의 TCI는 태 백산맥 산악 지역과 영동 지역에서 약한 증가가 나 타나지만 영서 지역에서 반대로 약한 감소가 나타 나는 특징을 보인다. 21세기 후반으로 갈수록 여 름철 $\mathrm{TCI}$ 는 6 월에 태백산맥을 중심으로 나타나는 약한 증가를 제외하면 전체적으로 감소하고, 그 감소의 정도는 7월부터 8 월까지 점차 뚜렷하게 나 타나는데 영동 지역보다 영서 지역에서 더 지배적 으로 나타난다. 9월부터 태백산맥을 중심으로 약 한 TCI의 증가가 다시 나타나다가 10-12월에 걸 쳐 강원도 전 지역의 $\mathrm{TCI}$ 가 증가하는 것으로 전망 되었다. 즉, 21세기 후반으로 갈수록 6-9월은 태 백산맥의 중심 지역을 제외한 나머지 지역에 대하 여 관광하기 점차 불쾌해지며, 특히 영서 지역에 서 8 월의 기후 조건이 관광하는 데 가장 불리해짐 을 의미한다. 반면, 나머지 계절은 5 월의 영서 지 역을 제외하면 강원도 전 지역에 대하여 점차 쾌적 한 기후 조건이 됨을 의미한다.

Figure 5와 Figure 6은 강원도 지역의 RCP8.5 시나리오 하에서 전망된 $\mathrm{TCI}$ 의 21 세기 초반 10 년 (2011-2020년)과 후반 10년(2091-2100년) 월 평 균 공간분포도이다. 21세기 초반 $\mathrm{TCI}$ 는 6 월과 10 월을 제외하고 태백산맥을 중심으로 지역적 차이 가 뚜렷하게 나타난다. 1월부터 5월까지 태백산맥 중심 지역에서 $\mathrm{TCI}$ 가 최소가 나타나며, 5월로 갈 수록 TCI는 '매우 나쁨-나쁨'에서 '좋음-매우 좋 음'까지 쾌적도의 단계가 상승하는 것으로 나타난 다. 6 월의 $\mathrm{TCI}$ 는 대부분 강원도 지역에서 70 이상 으로 관광하기 '매우 좋음'에 해당하는 기후 조건 을 보인다. 7월부터 8월까지 TCI는 점차 감소하며 영서 지역에서 뚜렷한 감소를 보이고, 태백산맥 중심 지역의 TCI가 ‘좋음'으로 영동 지역과 영서 

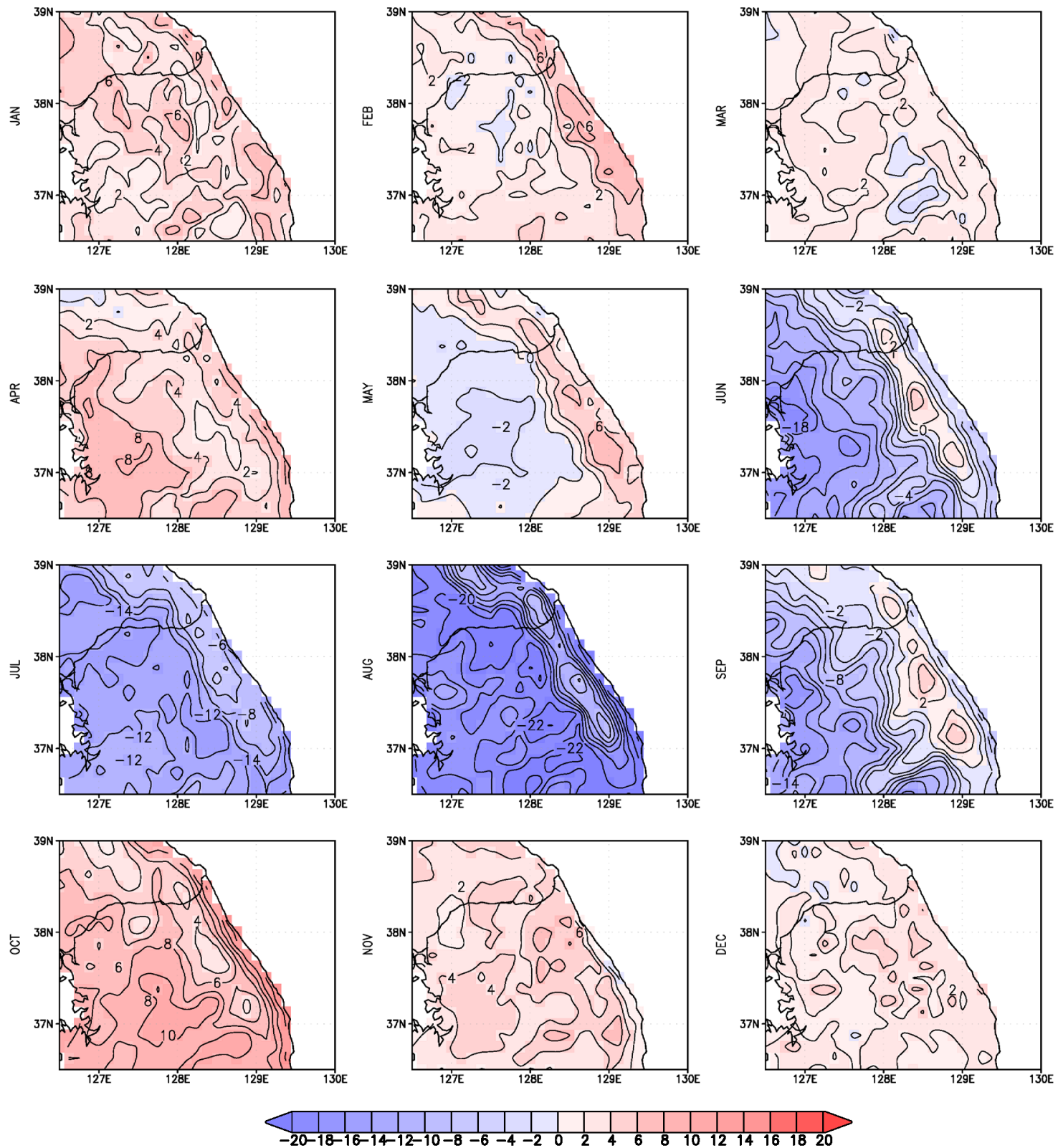

Figure 4. Difference fields of monthly TCl between the last decade(2091-2100) and the first decade(2011-2020) of the 21 st century in Gangwon region under the RCP4.5 scenario.

지역에 비해 높게 나타난다. 즉, RCP4.5 시나리오 와 마찬가지로 여름철 관광 활동은 태백산맥의 산 악 지역이 다른 지역보다 관광활동을 하는데 기후 조건에 있어 유리함을 의미한다. TCI는 9월에 다
시 전 지역에 걸쳐 증가하고 영서 지역이 다른 지 역에 비해 증가 정도가 더 큰 것으로 나타난다. 10 월의 $\mathrm{TCI}$ 는 9월보다 소폭 감소하지만 '괜찮음-좋 음'으로 관광하기 알맞은 기후 조건이다. 11-12월 

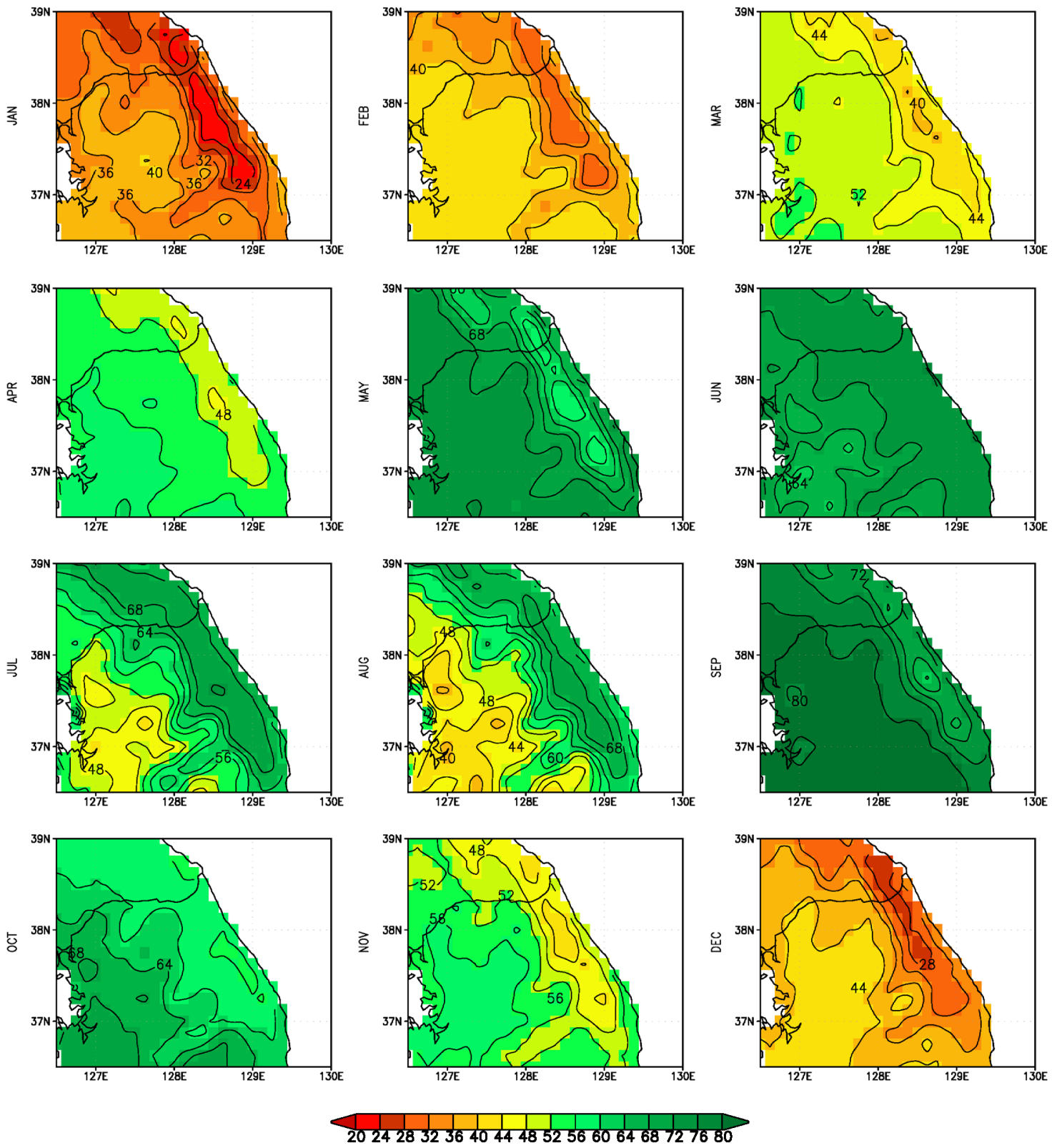

Figure 5. Projected distribution of monthly TCl for the first decade(2011-2020) of the 21st Century in Gangwon region under the RCP8.5 scenario.

까지 TCI는 계속 감소하면서 태백산맥을 중심으 로 다시 최소가 나타나며, 12월에 태백산맥의 중 심 지역은 '매우 나쁨'으로 관광활동에 불리한 기 후 조건을 보인다. 21 세기 후반 $\mathrm{TCI}$ 는 21 세기 초
반 10 년에 비해 더욱 뚜렷한 지역적 차이가 나타난 다. 겨울철(12, 1, 2월) TCI는 태백산맥을 중심으 로 최소가 나타나며 21세기 초반에 비해 증가하는 것으로 나타난다. 3월과 4월에서도 태백산맥에서 

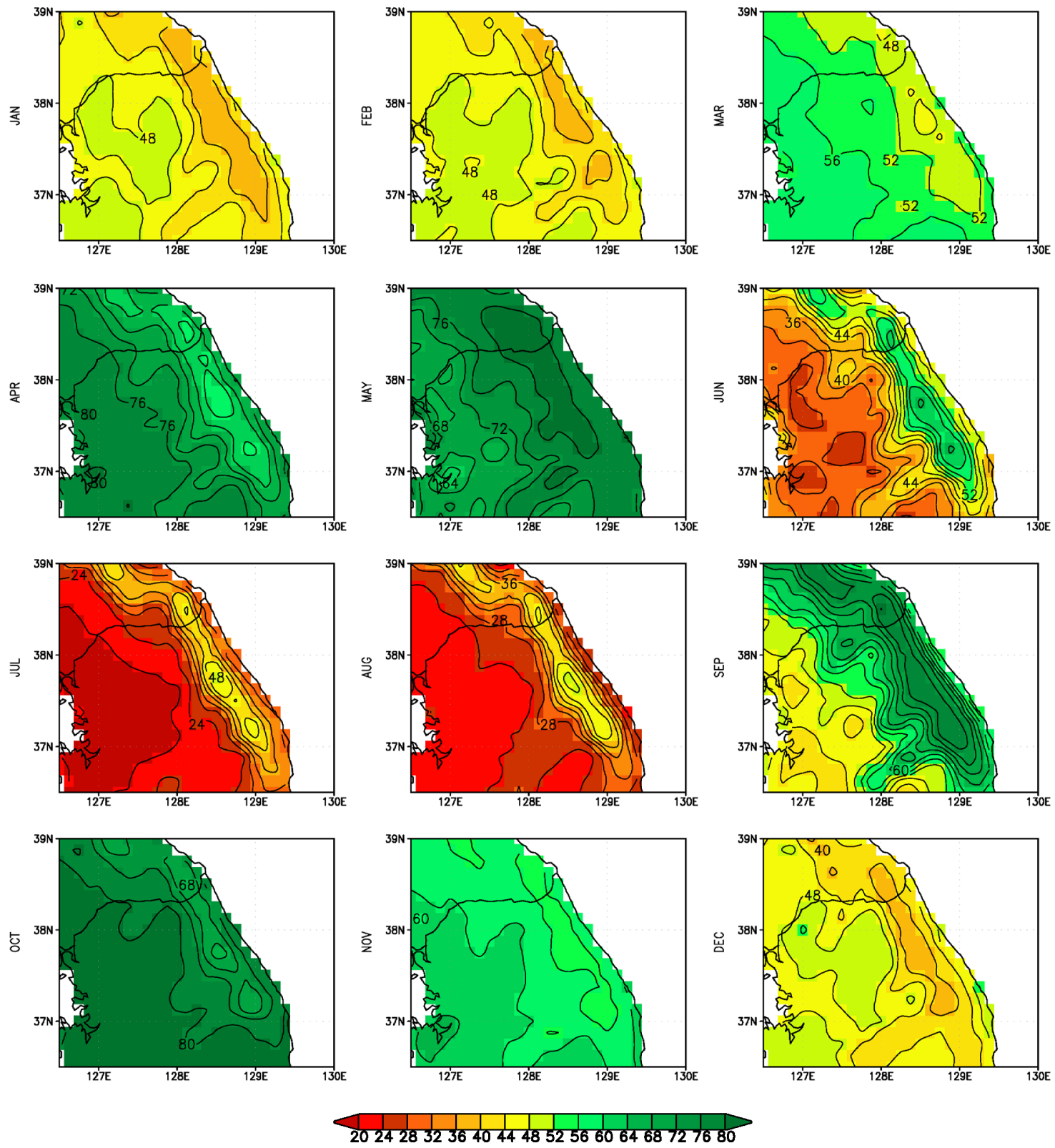

Figure 6. Same as Figure 5 except for the last decade(2091-2100).

TCI가 최소로 나타나는 현상은 유지되며, 4월부 터 영동 지역과 영서 지역 일부에서 TCI가 '매우 좋음'을 보인다. 5월의 TCI는 21 세기 초반과 달리 태백산맥을 중심으로 최대가 나타나며 대부분 지
역에서 '매우 좋음'을 보인다. 그러나 6월의 TCI는 21 세기 초반에 비해 작게 나타나고 태백산맥 중심 지역을 제외한 영동 지역과 영서 지역에서 뚜렷한 감소를 확인할 수 있다. 또한, 태백산맥 중심 지역 
으로 갈수록 TCI의 급격한 변화가 나타난다. 7-8 월의 $\mathrm{TCI}$ 는 21 세기 초반에 비해 확연히 작게 나타 나고 태백산맥 중심 지역이 영동 지역과 영서 지역 에 비해 TCI가 크게 나타나지만 그 중심값이 21세 기 초반의 '좋음'에서 '좋지도 나쁘지도 않음'으로 2 단계 하락하였다. 특히, 영서 지역의 TCI가 다른 지역에 비해 최소로 나타난다. 이는 다른 지역에 비해 비교적 관광활동에 좋은 기후 조건을 보였던 태백산맥의 산악지역도 21세기 후반으로 갈수록 피서지로써의 매력도가 낮아짐을 의미한다. 9월부 터는 태백산맥을 중심으로 TCI가 점차 증가하고, 태백산맥 중심 지역에 $\mathrm{TCI}$ 의 최소가 나타나는 21 세기 초반과 달리 TCI의 최대가 나타나는 특징을 보인다. 10 월의 TCI는 21 세기 초반에 비해 태백 산맥을 제외하고 높게 나타나며, 영서 지역의 일 부는 '훌륭함'에 해당한다. 11-12월로 갈수록 TCI 는 점차 감소하고 태백산맥 중심으로 최소가 나타 나나 21세기 초반에 비해 증가하는 것으로 나타난 다. 즉, 21 세기 후반의 관광 활동은 여름에 취약해 지며 겨울에 기후 조건이 다소 유리해짐을 의미한 다. Figure 7은 RCP8.5 시나리오 하에서 전망된 21 세기 후반 10 년과 초반 10 년간의 TCI의 차이에 대한 분포이다. 6-9월을 제외한 나머지 달은 강원 도 전 지역에서 $\mathrm{TCI}$ 가 증가하고, 특히 4 월과 10 월 에 태백산맥을 제외한 영동 지역과 영서 지역, 5월 에 태백산맥을 중심 지역에서 가장 크게 증가하는 것으로 나타난다. 6-9월의 TCI는 9월의 태백산 맥 중심 지역을 제외한 나머지 지역에서 강한 감소 를 보이고 영동 지역보다 영서 지역에서 지배적이 다. 이는 RCP4.5 시나리오 하에서 전망된 21세기 후반과 초반의 TCI 차이보다 더욱 뚜렷한 차이를 보인다. 즉, 저배출 시나리오보다 고배출 시나리 오에서의 여름철 관광활동은 강원도 전 지역의 관 광 활동을 하는데 있어 기후 조건이 더욱 불리해지 는 부정적인 효과가 나타나고, 겨울철 관광 활동
은 태백산맥을 중심으로 강원도 전 지역의 기후 조 건이 유리해지는 비교적 긍정적인 효과가 나타남 을 의미한다.

\section{3) 21 세기 월별 $\mathrm{TCl}$ 의 변화 추세}

Table 5는 RCP4.5 및 RCP8.5 시나리오 하에서 전망된 강릉, 대관령, 원주, 그리고 춘천 지역에 대하여 2011-2100년 기간의 월별 TCI의 변화 추 세를 나타낸 것이다. 대관령을 제외한 강릉, 원주, 춘천 지역은 두 시나리오 하에서 전망된 6-9월에 공통적인 $\mathrm{TCI}$ 의 감소추세를 보이며, 대관령의 경 우 RCP8.5 시나리오 하에서 전망된 9월의 TCI가 10 년당 +1.08 율로 다른 지역과 반대 추세를 보이 는 것을 제외하면 6-8월에 감소 추세를 보인다. 이 감소 추세는 RCP4.5 시나리오보다 RCP8.5 시 나리오에서 더 뚜렷하게 나타난다. 나머지 달에 대해서는 대부분 증가 추세를 보이며, 특히 온난 화 영향으로 대체로 추운 계절에는 증가 추세가 나 타난다. RCP8.5 시나리오 하에서 전망된 춘천의 $\mathrm{TCI}$ 를 제외한 나머지 지역은 두 시나리오 모두 10 월의 TCI가 가장 크게 증가하는 것으로 전망되었 다. 이는 21 세기 후반으로 갈수록 여름철을 포함 한 6-9월에 야외 관광 활동이 기후변화에 취약해 질 것을 의미하고, 10 월을 포함한 나머지 달에 대 해 야외 관광 활동이 쾌적해질 것을 의미한다. 지 역적 · 계절적 편차가 크지만 몇 경우를 제외하고 는 RCP4.5 시나리오보다 RCP8.5 시나리오에서 약 2-3배의 증가(감소) 추세를 보이며, RCP8.5 시 나리오 하에서 전망된 원주와 춘천의 4 월 $\mathrm{TCI}$ 가 다른 지역에 비해 큰 증가 추세를 보이는 것이 특 징이다.

\section{4) 미래 TCI 변화에 영향을 미치는 기후요소들}

$\mathrm{TCI}$ 의 미래 변화 추세의 원인을 분석하기 위해 $\mathrm{RCP} 4.5$ 및 RCP8.5 시나리오 하에서 전망된 강원 

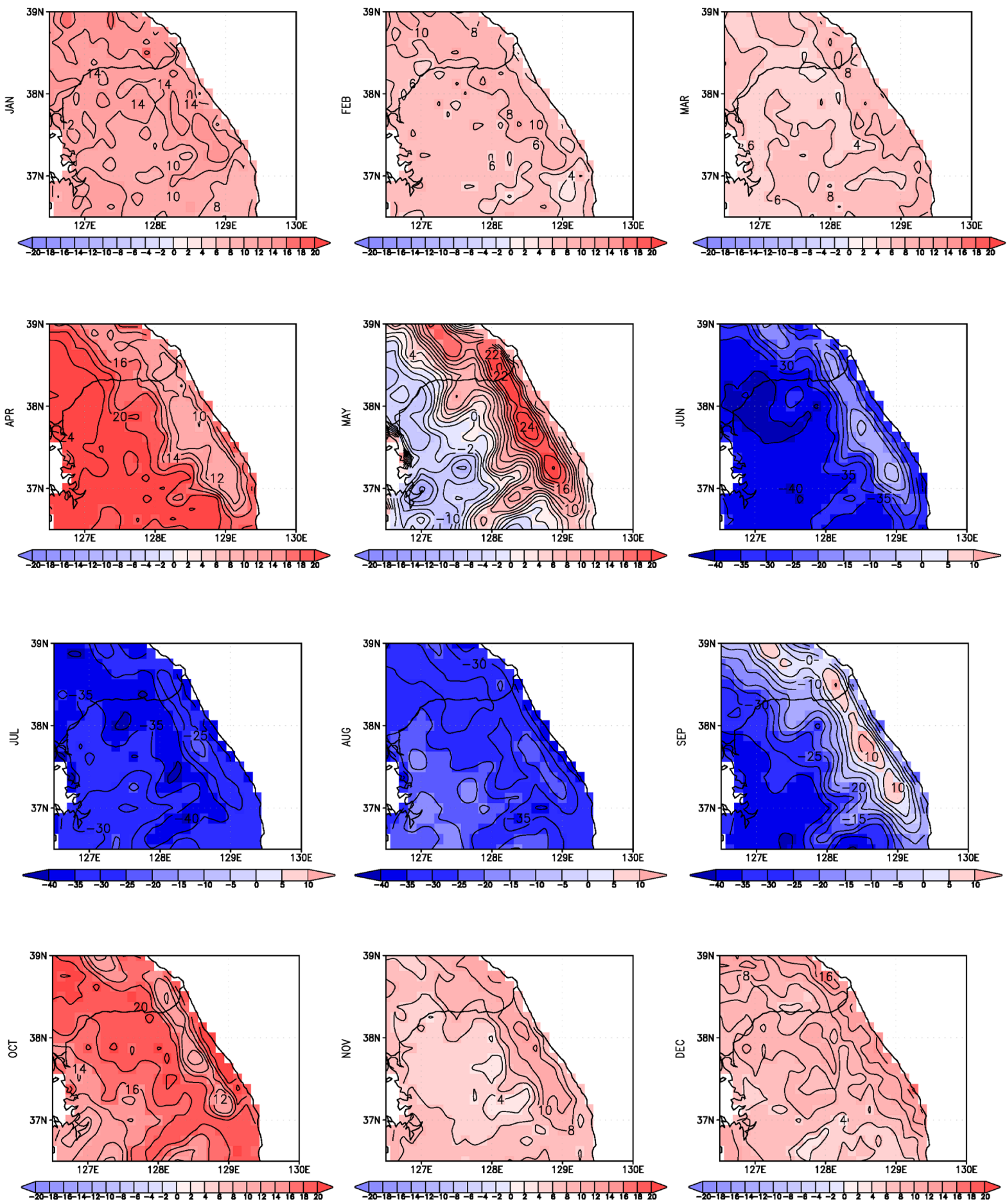

Figure 7. Difference fields of monthly TCI between the last decade(2091-2100) and the first decade(2011-2020) of the 21 st century in Gangwon region under the RCP8.5 scenario. 
Table 5. Long term trends (in decade ${ }^{-1}$ ) of monthly TCl at Gangneung, Daegwallyeong, Wonju, and Chuncheon under the RCP4.5 and RCP8.5 scenarios (2011-2100). Values are statistically significant at a 95\% confidence level except values with asterisk (*).

\begin{tabular}{c|c|c|c|c|c|c|c|c}
\hline \hline & \multicolumn{2}{|c|}{ Gangneung } & \multicolumn{2}{c|}{ Daegwallyeong } & \multicolumn{2}{c|}{ Wonju } & \multicolumn{2}{c}{ Chuncheon } \\
\hline & RCP4.5 & RCP8.5 & RCP4.5 & RCP8.5 & RCP4.5 & RCP8.5 & RCP4.5 & RCP8.5 \\
\hline Jan & $+0.32^{*}$ & +1.10 & $+0.26^{*}$ & +1.19 & $+0.14^{*}$ & +0.72 & $+0.06^{*}$ & +0.54 \\
Feb & $+0.43^{*}$ & $+0.33^{*}$ & +0.61 & $+0.03^{*}$ & $+0.06^{*}$ & $-0.09^{*}$ & $+0.11^{*}$ & $-0.15^{*}$ \\
Mar & $+0.32^{*}$ & +0.84 & $+0.34^{*}$ & +0.64 & $+0.13^{*}$ & $+0.46^{*}$ & $0.00^{*}$ & $+0.32^{*}$ \\
Apr & $+0.62^{*}$ & +1.67 & $+0.01^{*}$ & +1.14 & $+0.32^{*}$ & +2.21 & $+0.43^{*}$ & +2.24 \\
May & +0.74 & +1.35 & +0.85 & +2.10 & $+0.30^{*}$ & +1.30 & $+0.17^{*}$ & $+0.62^{*}$ \\
Jun & -0.48 & -1.80 & $-0.12^{*}$ & -0.70 & -0.82 & -3.36 & -1.22 & -3.95 \\
Jul & -1.61 & -3.93 & -1.07 & -3.02 & -1.70 & -3.49 & -1.69 & -3.32 \\
Aug & -1.85 & -4.21 & -0.76 & -2.65 & -2.38 & -3.74 & -2.16 & -3.11 \\
Sep & $-0.55^{*}$ & -1.10 & $-0.02^{*}$ & +1.08 & $-0.41^{*}$ & -2.09 & -1.21 & -3.83 \\
Oct & +1.59 & +2.95 & +0.88 & +2.41 & +1.43 & +2.40 & +1.61 & +1.50 \\
Nov & $+0.23^{*}$ & +0.98 & $+0.18^{*}$ & +0.96 & $+0.28^{*}$ & +0.62 & $+0.17^{*}$ & +0.58 \\
Dec & $+0.66^{*}$ & +1.18 & $+0.53^{*}$ & +1.08 & $+0.20^{*}$ & +0.59 & $+0.22^{*}$ & +0.63 \\
\hline \hline
\end{tabular}

도 4 개 지역의 $\mathrm{TCI}$ 를 대상으로 하여 각 하부지수 가 TCI에 기여하는 정도를 분석하였다. Figure 8 은 RCP4.5 시나리오 하에서 전망된 강릉 지역의 $\mathrm{TCI}$ 중 가장 큰 감소 추세를 보였던 8월의 TCI와 하부지수 $C I D, C I A, P, S$, 그리고 $W$ 의 변화 및 추 세를 나타낸 그림이다. $T C I, C I D, C I A, P, S$, 그 리고 $W$ 의 10 년당 변화율은 각각 $-1.85,-0.16$, $-0.08,-0.01,+0.03,-0.25$ 로 $S$ 를 제외한 나머 지 하부지수들은 $\mathrm{TCI}$ 와 같이 대체로 감소하는 추 세를 보이는 반면 $S$ 는 반대의 증가 추세를 보인 다. 각 하부지수들이 TCI 변화에 미치는 기여도는 $C I D(68.82 \%), W(26.88 \%), C I A(8.60 \%)$, 그리고 $P(2.15 \%)$ 순으로 양의 기여를 하였고, $S(-6.45 \%)$ 는 음의 기여를 하였다. 즉, RCP4.5 시나리오 하 에서 전망된 강릉 지역 8 월의 $\mathrm{TCI}$ 의 변화는 $W$ 의 변화 추세가 다른 하부지수의 변화 추세보다 큼에 도 불구하고 $C I D$ 의 변화에 기인한다. 이는 21 세기 후반으로 갈수록 관광 활동은 열적불쾌도에 의해 불리한 기후 조건이 됨을 의미한다. 그리고 일조
시간은 기여도가 $-6.90 \%$ 로 $\mathrm{TCI}$ 의 감소 추세를 조 금 완만하게 만드는 역할을 하는 반면, 강수량은 $\mathrm{TCI}$ 의 변화 추세에 거의 기여를 하지 않는데, 8 월 의 경우 월 강수량이 $150 \mathrm{~mm}$ 이상인 경우가 많아 거의 대부분의 $P$ 가 Table 1 의 배점 기준에 의해 0 점에 해당하여 추세에 영향을 주지 않는 것으로 사 료된다. Figure 9는 RCP4.5 시나리오 하에서 전망 된 강릉 지역 10 월의 $\mathrm{TCI}$ 와 하부지수 $C I D, C I A$, $P, S$, 그리고 $W$ 의 변화 및 추세를 나타낸 그림이 다. $T C I, C I D, C I A, P, S$, 그리고 $W$ 의 10 년당 변 화율은 각각 $+1.59,+0.14,+0.06,+0.07,+0.01$, 0.00 으로 $W$ 를 제외한 나머지 지수는 TCI와 같은 증가 추세를 보인다. 반면, $W$ 는 2017년을 제외한 나머지 해에 모두 5점 만점으로 추세가 거의 나타 나지 않았다. 각 하부지수들이 TCI 변화에 미치는 기여도는 $\operatorname{CID}(71.79 \%), P(17.95 \%), C I A(7.69 \%)$, $S(2.56 \%)$, 그리고 $W(0.00 \%)$ 순으로 높았다. 즉, $\mathrm{RCP} 4.5$ 시나리오 하에서 전망된 강릉 지역 10 월 의 $\mathrm{TCI}$ 의 변화에 $C I D$ 의 변화가 가장 큰 기여를 

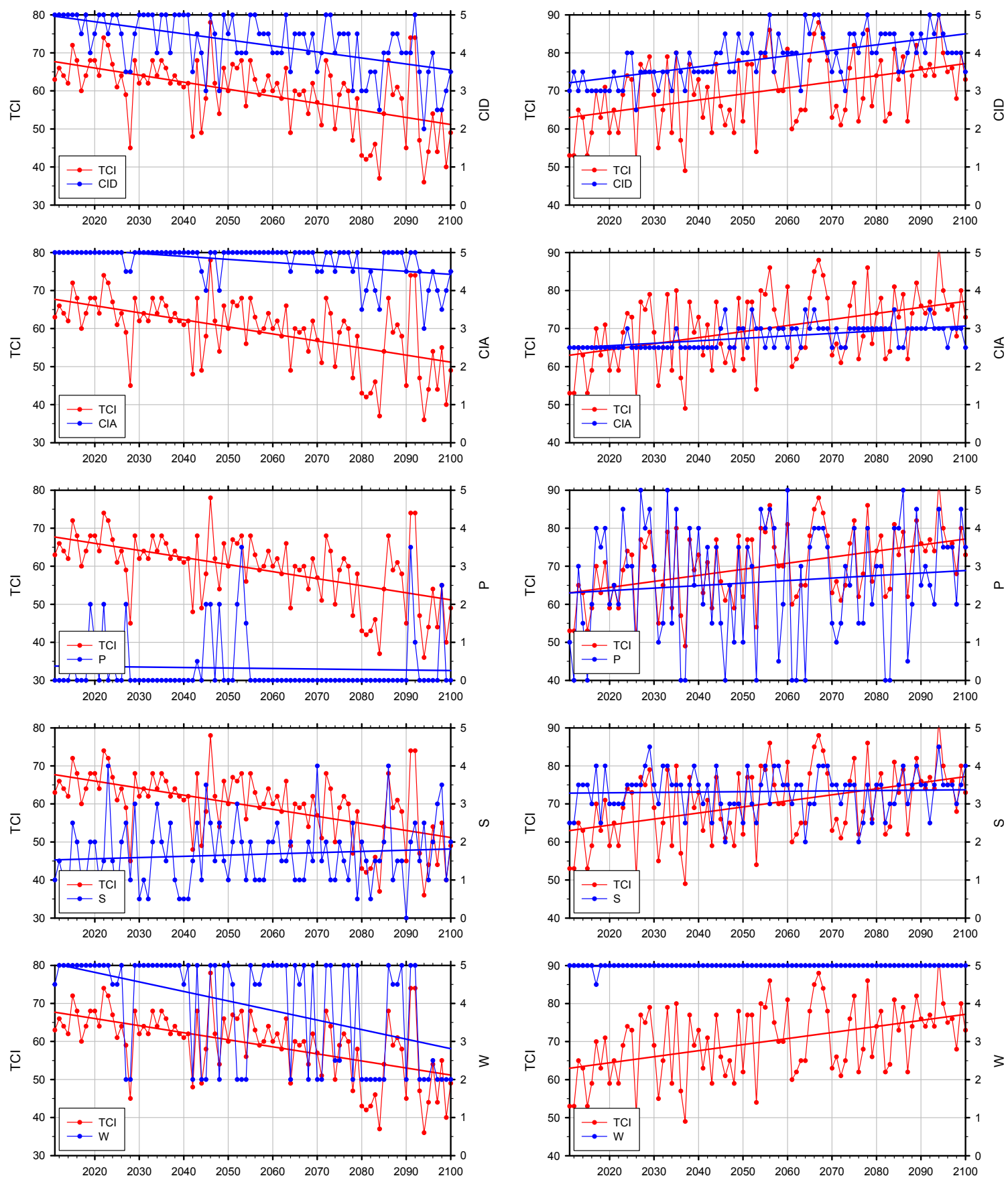

Figure 8. Changes of TCI, CID, CIA, P, S, and W for August at Gangneung under the RCP4.5 scenario

Figure 9. Same as Figure 8 execpt for October. (2011-2100). 
하고, $C I D$ 와 $P$ 의 장기 변화 추세로 $\mathrm{TCI}$ 의 추세 를 약 $89 \%$ 이상 설명할 수 있다. 이는 21세기 후반 으로 갈수록 관광활동의 쾌적함이 열적으로 가장 유리해짐을 의미한다. 8 월에 비해 10 월의 강수량 은 TCI의 변화에 기여하는 정도가 비교적 높게 나 타났고, 이는 강수량이 적어짐에 따라 관광활동이 쾌적해짐을 의미한다. 시나리오 별 모든 달에 대 한 TCI의 미래 변화 추세의 원인을 분석하기 위해 Table 6과 같이 RCP4.5 및 RCP8.5 시나리오 하에 서 전망된 강릉 지역 $\mathrm{TCI}$ 의 월별 변화 추세와 하 부지수 $C I D, C I A, P, S$, 그리고 $W$ 의 월별 변화 추 세를 정리하였다. RCP4.5 시나리오 하에서 전망 된 강릉 지역 $\mathrm{TCI}$ 의 변화는 2월, 6월, 9월, 그리고 12 월을 제외한 나머지 달에 대하여 $C I D$ 의 변화가 가장 크게 기여하는 것으로 나타나고 2월, 6월, 9 월, 그리고 12 월의 $\mathrm{TCI}$ 의 변화는 $\mathrm{P}$ 와 $\mathrm{S}$ 의 변화에 의존하는 것으로 나타난다. 특히, 9월의 TCI의 변 화 추세의 경우 $C I D$ 의 변화에 대한 기여는 전혀 없는 것으로 나타나며, $P$ 의 변화에 대한 기여도가
약 $78.57 \%$ 로 가장 높게 나타난다. $W$ 의 변화는 다 른 지수들에 비해 비교적 기여 정도가 낮은 것으로 나타났다. 이는 TCI를 계산하는 데 풍속의 가중치 가 작고, 강릉지역의 풍속이 미래에도 변화가 거 의 나타나지 않는 이유로 사료된다. RCP8.5 시나 리오 하에서 전망된 강릉 지역 $\mathrm{TCI}$ 의 변화는 5 월 을 제외한 나머지 달에 대하여 RCP4.5 시나리오 와 마찬가지로 $C I D$ 의 변화가 가장 큰 기여를 하는 것으로 나타났고, 5 월의 $\mathrm{TCI}$ 의 변화는 $C I A$ 의 변 화의 기여가 가장 크지만 나머지 하부지수들 또한 고르게 기여하는 것으로 나타났다.

강릉 지역뿐 아니라 나머지 3 개 지점에 대해서 도 TCI의 미래 변화에 대한 원인 분석을 수행하 였다. Table 7은 RCP4.5 및 RCP8.5 시나리오 하 에서 전망된 대관령 지역의 $\mathrm{TCI}$ 의 월별 변화 추 세와 하부지수 $C I D, C I A, P, S$, 그리고 $W$ 의 월 별 변화 추세를 나타낸 표이다. 감소 추세가 가 장 크게 나타난 RCP4.5 시나리오 하에서의 8월 과 RCP8.5 시나리오 하에서의 7월의 $\mathrm{TCI}$ 변화에

Table 6. Long term trends (in decade ${ }^{-1}$ ) of monthly TCI, CID, CIA, P, S, and W at Gangneung under the RCP4.5 and RCP8.5 scenarios (2011-2100). * and ${ }^{* *}$ indicate the values are statistically significant at the $90 \%$ and $95 \%$ confidence levels, respectively.

\begin{tabular}{|c|c|c|c|c|c|c|c|c|c|c|c|c|}
\hline \multirow{2}{*}{ M } & \multicolumn{6}{|c|}{ RCP4.5 } & \multicolumn{6}{|c|}{ RCP8.5 } \\
\hline & TCI & CID & CIA & $\mathrm{P}$ & S & W & TCI & CID & CIA & $\mathrm{P}$ & S & W \\
\hline Jan & +0.32 & $+0.03^{* *}$ & $+0.04^{* * *}$ & -0.01 & +0.01 & -0.01 & $+1.19 * *$ & $+0.07^{* *}$ & $+0.10 * *$ & +0.04 & $+0.04^{*}$ & 0.00 \\
\hline Feb & +0.43 & $+0.02 * *$ & $+0.04^{* *}$ & +0.04 & +0.01 & 0.00 & +0.03 & $+0.10 * *$ & $+0.10 * *$ & $-0.15 * *$ & -0.02 & +0.01 \\
\hline Mar & +0.32 & $+0.02 * *$ & $+0.02 * *$ & +0.02 & +0.02 & -0.01 & $+0.64^{* *}$ & $+0.07^{* *}$ & $+0.07^{* *}$ & 0.00 & +0.03 & 0.00 \\
\hline Apr & $+0.62 *$ & $+0.05^{* *}$ & $+0.03^{* *}$ & +0.02 & +0.02 & $+0.01^{* *}$ & $+1.14^{* *}$ & $+0.18^{* *}$ & $+0.06^{* *}$ & +0.01 & +0.03 & 0.00 \\
\hline May & $+0.74^{* *}$ & $+0.04^{* *}$ & $+0.10 * *$ & -0.01 & $+0.07^{*}$ & 0.00 & $+2.10 * *$ & $+0.04^{* *}$ & $+0.23^{* *}$ & +0.05 & $+0.08^{*}$ & 0.00 \\
\hline Jun & $-0.48^{* *}$ & $-0.02 * *$ & $+0.02 * *$ & -0.02 & -0.06 ** & 0.00 & $-0.70^{* * *}$ & $-0.15^{* *}$ & +0.01 & -0.08 & +0.05 & $-0.22 * *$ \\
\hline Jul & $-1.61^{* *}$ & $-0.11^{* *}$ & $-0.05^{* *}$ & -0.05 & -0.03 & $-0.14^{* *}$ & $-3.02^{* *}$ & $-0.32^{* *}$ & $-0.25^{* *}$ & $-0.09^{* *}$ & +0.03 & $-0.31^{* *}$ \\
\hline Aug & $-1.85^{* *}$ & $-0.16^{* *}$ & $-0.08^{* *}$ & -0.01 & +0.03 & $-0.25^{* *}$ & $-2.65 * *$ & $-0.38^{* *}$ & $-0.32^{* *}$ & -0.01 & +0.06 & $-0.36^{* *}$ \\
\hline Sep & $-0.55^{*}$ & 0.00 & $+0.04^{* * *}$ & $-0.11^{*}$ & -0.05 & 0.00 & $+1.08^{* *}$ & $-0.11^{* *}$ & $+0.01^{*}$ & -0.03 & $+0.05^{*}$ & $-0.15^{* *}$ \\
\hline Oct & $+1.59 * *$ & $+0.14 * *$ & $+0.06^{* *}$ & +0.07 & 0.01 & 0.00 & $+2.41^{* *}$ & $+0.25 * *$ & $+0.24^{* *}$ & +0.09 & +0.02 & $+0.01^{*}$ \\
\hline Nov & +0.23 & $+0.04^{* * *}$ & $+0.02 * *$ & -0.01 & -0.02 & 0.00 & $+0.96^{* *}$ & $+0.07 * *$ & $+0.08^{* *}$ & +0.04 & +0.02 & 0.00 \\
\hline Dec & $+0.66^{*}$ & $+0.02^{* *}$ & +0.01 & +0.07 & $+0.04^{* *}$ & -0.01 & $+1.08^{* *}$ & $+0.07^{* *}$ & $+0.06^{* *}$ & +0.08 & +0.03 & $+0.02^{* *}$ \\
\hline
\end{tabular}


$C I D$ 의 변화가 각각 $77.78 \%, 66.67 \%$ 의 기여도로 가장 높게 기여하는 것으로 나타났으며, $P$ 와 $W$ 의 변화의 기여도가 나머지를 차지하였다. 증가 추세 가 가장 크게 나타난 RCP4.5 및 RCP8.5 시나리 오 하에서의 10 월의 TCI 변화 또한 $C I D$ 의 변화 가 각각 $62.22 \%, 80.00 \%$ 로 높은 기여도를 보였다. $\mathrm{RCP} 4.5$ 시나리오 하에서의 2월, 6월, 그리고 12 월 과 RCP8.5 시나리오 하에서의 2월과 9월에 대한 $\mathrm{TCI}$ 의 변화는 $C I A, P, S$ 의 변화에 의해 설명이 가 능하며, 그 나머지 달에 대한 $\mathrm{TCI}$ 의 변화는 대부 분 $C I D$ 의 변화에 의해 설명이 가능하다. 즉, 산악 지역에 해당하는 대관령 지역의 $\mathrm{TCI}$ 의 변화는 대 부분 열적쾌적도의 변화에 의해 의존하는 것으로 나타났다.

Table 8과 Table 9는 각각 영서 지역인 원주와 춘천 지역에서의 $\mathrm{RCP} 4.5$ 및 $\mathrm{RCP} 8.5$ 시나리오 하에서 전망된 $\mathrm{TCI}$ 의 월별 변화 추세와 부지수 $C I D, C I A, P, S$, 그리고 $W$ 의 월별 변화 추세를 나 타낸 표이다. RCP4.5 및 RCP8.5 시나리오 하에 서 전망된 영서지역의 $\mathrm{TCI}$ 가 감소하는 추세를 보
이는 6-9월에 대하여 다른 달에 비해 W의 변화 추세가 뚜렷하게 나타나며, RCP4.5 시나리오 하 에서 전망된 원주 지역 9월의 $\mathrm{TCI}$ 의 변화를 제외 하면 $C I D$ 의 변화가 $\mathrm{TCI}$ 의 감소 추세에 가장 크게 기여하는 것으로 나타났다. RCP4.5 시나리오 하 에서의 춘천지역 1 월, 2 월, 5 월, 그리고 9월의 $\mathrm{TCI}$ 변화는 $C I D$ 의 변화 외에 $C I A, P, S$ 의 변화가 크게 기여하는 것으로 나타났다.

$\mathrm{RCP}$ 시나리오에 따른 강원도 4 개 지역(강릉, 대 관령, 원주, 춘천)에서의 $\mathrm{TCI}$ 의 미래 변화 추세에 대한 원인을 분석한 결과 미래 TCI의 변화는 주로 $C I D$ 의 변화에 의해 설명이 가능하며, 일부 계절 에 대하여 $C I A, P, S$ 의 변화가 큰 기여를 하는 것 으로 나타났다. 즉, 미래의 관광활동은 열적쾌적 도의 변화에 의존하며, 열적쾌적도(불쾌도)는 겨 울철(여름철) 관광활동은 열적으로 유리(불리)하게 적용된다.

$\mathrm{TCI}$ 의 경년변동성에 대한 상관성을 분석하기 위해 Table 10과 같이 RCP4.5 시나리오 하에서 전 망된 강릉 지역의 $\mathrm{TCI}$ 를 대상으로 하여 월 별 $\mathrm{TCI}$

Table 7. Same as Table 6 except for Daegwallyeong.

\begin{tabular}{|c|c|c|c|c|c|c|c|c|c|c|c|c|}
\hline \multirow{2}{*}{ M } & \multicolumn{6}{|c|}{ RCP4.5 } & \multicolumn{6}{|c|}{ RCP8.5 } \\
\hline & TCI & CID & CIA & $\mathrm{P}$ & S & W & TCI & CID & CIA & $\mathrm{P}$ & S & W \\
\hline Jan & +0.26 & $+0.03^{* *}$ & $+0.08 * *$ & -0.04 & 0.00 & -0.01 & +1.19 ** & $+0.11^{* *}$ & $+0.16^{* *}$ & -0.03 & +0.03 & -0.01 \\
\hline Feb & $+0.61^{* *}$ & $+0.03^{* *}$ & $+0.07^{* *}$ & +0.06 & 0.00 & 0.00 & +0.03 & $+0.09^{* *}$ & $+0.19^{* *}$ & $-0.21^{* *}$ & -0.03 & -0.01 \\
\hline Mar & +0.34 & $+0.02^{* * *}$ & $+0.02^{* *}$ & +0.02 & +0.01 & 0.00 & $+0.64^{* *}$ & $+0.06^{* * *}$ & $+0.07^{* * *}$ & -0.05 & $+0.04^{*}$ & +0.01 \\
\hline Apr & +0.01 & $+0.02^{*}$ & $+0.03^{* *}$ & -0.02 & -0.01 & +0.01 & $+1.14 * *$ & $+0.10 * *$ & $+0.07^{* * *}$ & +0.03 & +0.03 & +0.00 \\
\hline May & $+0.85 * *$ & $+0.07 * *$ & $+0.05^{* *}$ & -0.02 & +0.06 & +0.01 & $+2.10^{* * *}$ & $+0.12^{* *}$ & $+0.22^{* *}$ & +0.08 & $+0.09 * *$ & +0.01 \\
\hline Jun & -0.12 & 0.00 & $+0.07^{* *}$ & -0.02 & -0.04 & 0.00 & $-0.70^{* *}$ & $-0.08^{* *}$ & $+0.11^{* *}$ & $-0.10^{*}$ & +0.02 & +0.00 \\
\hline Jul & $-1.07^{* *}$ & $-0.07^{* *}$ & +0.01 & -0.05 & -0.03 & $-0.11^{* *}$ & $-3.02 * *$ & $-0.25 * *$ & $-0.11^{* *}$ & $-0.08^{*}$ & +0.03 & $-0.29 * *$ \\
\hline Aug & $-0.76^{* *}$ & $-0.07^{* *}$ & +0.01 & -0.03 & +0.01 & $-0.05^{* *}$ & $-2.65^{* *}$ & $-0.28^{* *}$ & $-0.09^{* *}$ & +0.07 & +0.04 & -0.30 ** \\
\hline Sep & -0.02 & $+0.05 * *$ & $+0.17^{* *}$ & $-0.11^{*}$ & $-0.07^{* *}$ & -0.01 & $+1.08^{* *}$ & $+0.04^{* *}$ & $+0.26^{* *}$ & +0.02 & +0.05 & +0.00 \\
\hline Oct & $+0.88^{* *}$ & $+0.07 * *$ & $+0.04 * *$ & +0.05 & +0.01 & $+0.01^{* *}$ & $+2.41 * *$ & $+0.24^{* *}$ & $+0.09 * *$ & +0.06 & +0.01 & $+0.01^{*}$ \\
\hline Nov & +0.18 & $+0.02 * *$ & $+0.03^{* *}$ & 0.00 & -0.02 & 0.00 & $+0.96^{* * *}$ & $+0.08 * *$ & $+0.08^{* * *}$ & +0.02 & +0.02 & +0.01 \\
\hline Dec & $+0.53^{*}$ & +0.02 & $+0.02 * *$ & +0.05 & $+0.04 * *$ & -0.01 & $+1.08 * *$ & $+0.07 * *$ & $+0.08 * *$ & +0.05 & $+0.05^{* *}$ & +0.01 \\
\hline
\end{tabular}


Table 8. Same as Table 6 except for Wonju.

\begin{tabular}{|c|c|c|c|c|c|c|c|c|c|c|c|c|}
\hline \multirow{2}{*}{ M } & \multicolumn{6}{|c|}{ RCP4.5 } & \multicolumn{6}{|c|}{ RCP8.5 } \\
\hline & TCI & CID & CIA & $\mathrm{P}$ & $S$ & W & TCI & CID & CIA & $\mathrm{P}$ & S & W \\
\hline Jan & +0.14 & $+0.03^{* *}$ & $+0.08 * *$ & $-0.05^{*}$ & -0.01 & 0.00 & $+0.72 * *$ & $+0.08^{* * *}$ & $+0.13^{* *}$ & $-0.08^{*}$ & +0.03 & 0.00 \\
\hline Feb & +0.06 & $+0.02^{* *}$ & $+0.03^{* *}$ & -0.04 & 0.00 & 0.00 & -0.09 & $+0.08 * *$ & $+0.08 * *$ & $-0.18^{* *}$ & $-0.04^{* *}$ & $+0.01^{*}$ \\
\hline Mar & +0.13 & $+0.02^{* *}$ & $+0.03^{* *}$ & -0.03 & +0.01 & $+0.01^{* *}$ & $+0.46^{*}$ & $+0.07^{* * *}$ & $+0.08 * *$ & -0.08 & +0.01 & 0.00 \\
\hline Apr & +0.32 & $+0.08^{* *}$ & $+0.02 * *$ & -0.07 & -0.02 & 0.00 & $+2.21^{* *}$ & $+0.23^{* *}$ & $+0.06 * *$ & +0.03 & +0.02 & 0.00 \\
\hline May & +0.30 & $+0.01^{*}$ & $+0.11^{* *}$ & -0.07 & $+0.07^{*}$ & 0.00 & $+1.30 * *$ & -0.01 & $+0.23^{* *}$ & $+0.11^{*}$ & $+0.11^{* *}$ & 0.00 \\
\hline Jun & $-0.82^{* *}$ & $-0.10 * *$ & 0.00 & +0.01 & 0.00 & -0.01 & $-3.36^{* *}$ & $-0.29 * *$ & $-0.06 * *$ & -0.08 & +0.02 & $-0.36 * *$ \\
\hline Jul & $-1.70 * *$ & $-0.14^{* *}$ & $-0.09^{* *}$ & +0.01 & -0.01 & $-0.19^{* *}$ & $-3.49 * *$ & $-0.36 * *$ & $-0.32 * *$ & +0.03 & $+0.08^{*}$ & $-0.19^{* *}$ \\
\hline Aug & $-2.38^{* *}$ & $-0.22^{* *}$ & $-0.15^{* *}$ & +0.01 & +0.01 & $-0.22^{* *}$ & $-3.74 * *$ & $-0.42 * *$ & $-0.38 * *$ & +0.08 & $+0.09^{* *}$ & $-0.17^{* *}$ \\
\hline Sep & -0.41 & $-0.02 * *$ & $+0.06 * *$ & -0.06 & -0.03 & 0.00 & $-2.09 * *$ & $-0.25 * *$ & $+0.02 * *$ & 0.00 & +0.04 & $-0.17 * *$ \\
\hline Oct & $+1.43^{* *}$ & $+0.15 * *$ & $+0.02^{* *}$ & +0.03 & +0.02 & 0.00 & $+2.40 * *$ & $+0.24^{* *}$ & $+0.16^{* *}$ & +0.02 & +0.02 & 0.00 \\
\hline Nov & +0.28 & $+0.03^{* *}$ & $+0.04^{* *}$ & 0.00 & -0.02 & 0.00 & $+0.62 * *$ & $+0.08 * *$ & $+0.07^{* *}$ & -0.06 & +0.02 & 0.00 \\
\hline Dec & +0.20 & 0.00 & +0.01 & 0.00 & $+0.04^{* *}$ & 0.00 & $+0.59^{* *}$ & $+0.06^{* *}$ & $+0.07^{* *}$ & -0.04 & $+0.04 * *$ & 0.00 \\
\hline
\end{tabular}

Table 9. Same as Table 6 except for Chuncheon.

\begin{tabular}{|c|c|c|c|c|c|c|c|c|c|c|c|c|}
\hline \multirow{2}{*}{ M } & \multicolumn{6}{|c|}{ RCP4.5 } & \multicolumn{6}{|c|}{ RCP8.5 } \\
\hline & TCI & CID & CIA & $\mathrm{P}$ & $S$ & W & TCI & CID & CIA & $\mathrm{P}$ & S & W \\
\hline Jan & +0.06 & $+0.03 * *$ & $+0.05 * *$ & -0.05 & -0.02 & +0.01 & $+0.54^{* * *}$ & $+0.07 * *$ & $+0.08 * *$ & -0.07 & +0.02 & +0.01 \\
\hline Feb & +0.11 & $+0.02^{*}$ & 0.00 & 0.00 & -0.01 & 0.00 & -0.15 & $+0.07 * *$ & $+0.08 * *$ & $-0.21^{* *}$ & -0.02 & +0.01 \\
\hline Mar & 0.00 & +0.02 & +0.01 & -0.06 & +0.01 & 0.00 & +0.32 & $+0.06^{* * *}$ & $+0.05 * *$ & -0.07 & +0.01 & 0.00 \\
\hline Apr & +0.43 & $+0.12 * *$ & $+0.01^{* *}$ & -0.10 & -0.03 & +0.01 & $+2.24^{* *}$ & $+0.23 * *$ & $+0.08 * *$ & +0.05 & +0.01 & 0.00 \\
\hline May & +0.17 & 0.00 & $+0.10 * *$ & -0.06 & +0.05 & 0.00 & +0.62 & $-0.07 * *$ & $+0.16^{* *}$ & $+0.11^{*}$ & $+0.11^{* *}$ & 0.00 \\
\hline Jun & $-1.22 * *$ & $-0.13^{* *}$ & $-0.01^{*}$ & 0.02 & 0.00 & $-0.15^{* *}$ & $-3.95 * *$ & $-0.35 * *$ & $-0.13^{* *}$ & -0.04 & +0.04 & $-0.46^{* *}$ \\
\hline Jul & $-1.69 * *$ & $-0.15 * *$ & $-0.15 * *$ & 0.01 & -0.01 & $-0.09^{* *}$ & $-3.32 * *$ & $-0.34 * *$ & $-0.37 * *$ & +0.04 & +0.05 & $-0.10 * *$ \\
\hline Aug & $-2.16^{* *}$ & $-0.21^{* *}$ & $-0.21^{* *}$ & 0.02 & +0.01 & $-0.09^{* *}$ & $-3.11^{* *}$ & $-0.37^{* *}$ & $-0.43^{* *}$ & +0.11 & +0.10 *** & $-0.06^{* * *}$ \\
\hline Sep & $-1.21^{* *}$ & $-0.11^{* *}$ & $+0.01 * *$ & -0.04 & -0.03 & -0.01 & $-3.83^{* *}$ & $-0.37 * *$ & $-0.06^{* *}$ & -0.01 & +0.03 & -0.39 \\
\hline Oct & $+1.61^{* *}$ & $+0.12^{* *}$ & $+0.05^{* *}$ & 0.03 & +0.02 & 0.00 & $+1.50 * *$ & $+0.13^{* *}$ & $+0.23^{* *}$ & -0.01 & +0.01 & 0.00 \\
\hline Nov & +0.17 & $+0.03^{* *}$ & $+0.02 * *$ & -0.01 & -0.01 & 0.00 & $+0.58 * *$ & $+0.08 * *$ & $+0.07 * *$ & -0.07 & +0.03 & 0.00 \\
\hline Dec & +0.22 & +0.01 & +0.02 & -0.01 & $+0.04 * *$ & 0.00 & $+0.63 * *$ & $+0.06 * *$ & $+0.06^{* *}$ & -0.05 & $+0.06 * *$ & 0.00 \\
\hline
\end{tabular}

와 $\mathrm{TCI}$ 의 변화에 가장 기여가 높았던 월평균기 온, 월평균 일조시간, 월 강수량 간의 상관관계를 조사하였다. 가장 뚜렷한 감소 추세를 보였던 8월 의 $\mathrm{TCI}$ 는 월평균기온과의 상관관계가 0.84 로 가 장 상관성이 높은 반면에, 월평균 일조시간과 월 강수량에 대해서는 각각 $0.19,-0.13$ 의 상관관계
로서 통계적으로 유의하지 않은 매우 낮은 상관 성을 보였다. 비슷한 감소 추세를 보였던 7월에서 도 월평균기온과의 상관관계가 0.83 으로 높은 상 관성을 보였으나 월평균 일조시간과 월 강수량에 대해서는 8월과 마찬가지로 낮은 상관성을 보였 다. 즉, 더운 여름철의 관광활동은 기온의 경년변 
Table 10. Correlation coefficients between monthly $\mathrm{TCl}$ and monthly mean temperature, monthly mean sunshine duration, and monthly precipitation at Gangneung under the RCP8.5 scenario (2011-2100). Values are statistically significant at a $95 \%$ confidence level except values with asterisk (*).

\begin{tabular}{c|c|c|c}
\hline \hline & Temperature & Sunshine duration & Precipitation \\
\hline Jan & 0.38 & 0.71 & -0.87 \\
Feb & $0.16^{*}$ & 0.73 & -0.82 \\
Mar & 0.39 & 0.78 & -0.79 \\
Apr & 0.72 & 0.77 & -0.73 \\
May & 0.66 & 0.78 & -0.66 \\
Jun & 0.32 & 0.26 & -0.51 \\
Jul & 0.83 & 0.29 & $-0.09^{*}$ \\
Aug & 0.84 & $0.19^{*}$ & $-0.13^{*}$ \\
Sep & 0.33 & 0.57 & -0.52 \\
Oct & 0.74 & 0.61 & -0.68 \\
Nov & 0.24 & 0.73 & -0.84 \\
Dec & 0.26 & 0.79 & -0.90 \\
\hline \hline
\end{tabular}

동성과 관계가 있고, 강수량과 일조시간은 그 관 계가 작은 것으로 파악된다. 증가 추세가 가장 뚜 렷했던 10 월의 $\mathrm{TCI}$ 는 월평균기온과 0.74 , 일조시 간과 0.61 , 월 강수량과 -0.68 의 상관계수를 보이 며 모든 기후요소들과의 다소 높은 상관성을 보였 다. 또한, 봄에 해당하는 4월과 5월에도 월평균기 온, 월평균 일조시간, 그리고 월 강수량과의 상관 관계가 높게 나타났다. 반면, 추운 계절에 해당하 는 11-2월의 TCI는 월평균기온과의 상관성이 거 의 없고 일조시간과 월강수량과의 상관관계가 높 았다. 특히, 2 월의 $\mathrm{TCI}$ 와 월평균기온간의 상관관 계는 0.16 으로 통계적으로 유의하지 않지만 가장 낮은 상관관계를 보였다. 즉 겨울철 TCI의 경년변 동성은 기온보다는 일조시간과 강수량에 의해 설 명될 수 있다. 일조시간과 강수량은 TCI의 감소추 세가 뚜렷했던 6-8월을 제외한 나머지 달에 대부 분 상관관계가 높게 나타났으며, 따라서 여름철을 제외한 $\mathrm{TCI}$ 의 경년변동성은 대부분 일조시간과 강수량에 의해 설명이 가능하다.

\section{4. 요약 및 결론}

본 연구에서는 강원도 지역을 대상으로 $\mathrm{RCP}$ 시 나리오 자료를 사용하여 미래 TCI를 산출하고, 이 를 통해 기후변화에 따른 관광 쾌적도의 평가를 비 롯한 관광 기후자원의 변화를 전망하고 그 변화에 대한 원인을 분석하고자 하였다.

강릉, 대관령, 춘천, 원주 4 개 지점에 대해 $\mathrm{RCP} 4.5$ 및 RCP8.5 시나리오 하에서 전망된 $\mathrm{TCI}$ 의 30 년 평균 연변화를 분석한 결과 강릉, 춘천, 원주는 봄과 가을에 TCI의 최대가 나타나고 여름 과 겨울에 최소가 나타나는 양봉피크형의 연변화 유형을 보였으며, 21 세기 후반으로 갈수록 여름철 에 나타나는 $\mathrm{TCI}$ 의 최소값이 더 작아지고 $\mathrm{RCP} 8.5$ 시나리오에서 더 작은 최솟값이 나타난다. 관측된 대관령의 TCI 연변화 유형은 여름에 $\mathrm{TCI}$ 가 최대 로 나타나는 여름피크형의 유형을 보였으나 기후 변화에 따라 21세기 후반에 여름철 TCI가 감소하 고, 나머지 계절의 $\mathrm{TCI}$ 는 증가하면서 양봉피크형 
의 연변화 유형으로 변화한다. 그 변화는 RCP8.5 시나리오에서 더 두드러진다. TCI의 공간분포를 분석한 결과, TCI는 7-8월에 태백산맥의 중심지 역이 타 지역에 비해 높게 나타나고, 나머지 계절 에서는 태백산맥에서 최소가 나타나는 지역적·계 절적 특징이 나타난다. 또한, 봄과 가을에 강원도 전 지역에 걸쳐 관광하기 쾌적한 상태가 되며 겨울 과 여름에는 대체로 관광 활동에 불쾌한 상태를 보 였다. 21 세기 후반으로 갈수록 겨울철 $\mathrm{TCI}$ 는 백두 대간을 따라 증가하고, 여름철 $\mathrm{TCI}$ 는 백두대간을 제외한 지역에서 대부분 감소하는 것으로 나타났 다. 강릉, 대관령, 춘천, 원주를 대상으로 RCP시 나리오에 따른 미래 전망 추세를 분석한 결과, 대 체로 더운 계절인 6-8월에 TCI가 뚜렷하게 감소 하는 추세를 보이고, 10 월을 포함한 나머지 계절 에는 증가하는 추세를 보였다. 즉, 21 세기 후반으 로 갈수록 여름철 관광활동은 기후변화에 따라 취 약해지고 겨울철 관광활동은 온난화로 인해 따뜻 해지면서 점차 쾌적해지는 것을 시사한다. $\mathrm{TCI}$ 의 미래 변화 추세에 대한 원인을 분석하기 위해 TCI 를 이루는 각 하부지수들의 추세분석을 통하여 기 여도를 조사하였다. 분석 결과, 감소(증가) 추세가 뚜렷했던 8월(10월)의 TCI는 CID 변화의 기여가 가장 높았으며, 이는 $\mathrm{TCI}$ 의 감소(증가)가 기후 변 화에 따라 열적으로 불리(유리)해지는 영향이 가장 큰 것을 시사한다. 또한, $\mathrm{TCI}$ 의 경년변동성은 여 름철을 제외한 나머지 계절에 대해 일조시간과 강 수량간의 상관관계가 가장 높게 나타나 일조시간 과 강수량의 경년변동으로서 설명이 가능하며, 여 름철 $\mathrm{TCI}$ 의 경년변동은 일조시간과 강수량보다 기온의 경년변동만으로 설명이 가능하다.

관광산업은 기후변화에 매우 민감한 산업이며 기후변화에 대한 관광산업부분의 적응 능력을 갖 추는 일이 중대한 문제로 대두되는 만큼 더욱 활발 한 TCI의 연구가 이루어져야할 것으로 사료된다.
따라서 우리나라 관광산업의 기후변화 적응을 위 해 강원도 지역 및 일부 지역에 국한하지 않고 남 한 전국으로 분석 범위를 확대하여 $\mathrm{TCI}$ 를 분석할 필요가 있다. 더불어 본 연구에서는 미래 $\mathrm{TCI}$ 를 산출하기 위해서 운량만을 고려한 일조시간을 처 방한 방법과 지점별 일조시간의 평년값을 처방한 방법을 사용하였지만 보다 정교한 TCI의 산출을 위해 정확한 일조시간의 처방을 필요로 하며, 이 에 따른 일조시간의 산출 방안에 대한 연구도 함께 이루어져야 할 것으로 사료된다.

\section{사사}

유익한 조언과 비판을 해주신 익명의 심사자께 깊이 감사드립니다. 이 논문은 2013년 기상청 지 역기후서비스 사업의 "강원도 지역축제(관광) 지 원을 위한 기후정보 개발"의 지원에 의하여 수행 되었습니다.

\section{참고문헌}

Amelung, B., Blazejczyk, K., and Matzarakis, A., 2007, Climate change and tourism-Assessment and coping strategies, Maastricht-Warsaw-Freiburg, ISBN 978-00-023716-4

Amelung, B., Nicholls, S., and Viner, D., 2007, Implications of global climate change for tourism flows and seasonality, J. Travel Res., 45(3), 285-296.

Amelung, B. and Viner, D., 2006, Mediterranean tourism: exploring the future with the Tourism Climatic Index, J. Sustain. Tour., 14, 349-366.

Cho, L.-N., 2009, Impacts of climate change on winter tourism industry: The current research trend in foreign countries, Journal of Climate Research, 4(2), 118-127 (in Korean).

Chung, I.-U., Lim, C.-M., and Yoon, J.-S., 2013, 
Change of tourism climate resources in Gangwon-do based on the tourism climatic index, Journal of Climate Research, 8(3), 237-251 (in Korean).

de Freitas, C. R., 2003, Tourism climatology: evaluating environmental information for decision making and business planning in the recreation and tourism sector, Int. J. Biometeorol., 48(1), 45-54.

de Freitas, C. R., Scott, D., and McBoyle, G., 2008, A second generation climate index for tourism (CIT): specification and verification, Int. J. Biometeorol., 52(5), 399-407.

Heo, I. H. and Lee, S. H., 2008a, The impact of climate changes on ski industries in South Korea: In the case of the Yongpyong ski resort, J. Korean Geographical Soc., 43(5), 715-727 (in Korean).

Heo, I. H. and Lee, S. H., 2008b, A study on climate changes and initial snow making on skiing ground: The case of Yongpyong ski resort, Journal of Climate Research, 3(2), 55-63 (in Korean).

Heo, I. H. and Lee, S. H., 2010, The impact of climate change on ski industry in central region of Korea: The case of Yongpyong.Yangji.Jisan ski resort, J. Korean Geographical Soc., 45(4), 444-460 (in Korean).

Heo, I. H. and Lee, S. H., 2012, The projection of regional ski industry by future climate data in South Korea: using A1B scenario, Journal of Climate Research, 7(1), 69-81 (in Korean).

IPCC, 2013, Climate Change 2013: The Physical Science Basis. Contribution of Working Group I to the Fifth Assessment Report of the Intergovernmental Panel on Climate Change [Stocker, T.F., D. Qin, G.-K. Plattner, M. Tignor, S.K. Allen, J. Boschung, A. Nauels, Y. Xia, V. Bex and P.M. Midgley (eds.)]. Cambridge University Press, Cambridge, United Kingdom and New York, NY, USA, 1535

Kim, S.-J., 2008, Countermeasure to climate change in the tourism sector, Korea Tourism Policy, 32, 7379 (in Korean).

Lim, C.-M. and Chung, I.-U., 2013, Development of sunshine duration estimation scheme using cloud amount and solar irradiance, Proceeding of 2013 Fall Meeing of the Korea Meteorological Society, 326-330.

MCST, 2009, Guideline for the Low Carbon Green Tourism Resources Development, Report of the Ministry of Culture, Sports, and Tourism, 39.

Mieczkowski, Z., 1985, The tourism climatic index: A method of evaluating world climates for tourism, The Canadian Geographer, 29(3), 220-233.

NIMR, 2012, Report on the Global Climate Change 2012 for Response to the 5th IPCC Assessment Report, $100 \mathrm{pp}$ (in Korean).

Osczevski, R. and Bluestein, M., 2005, The new wind chill equivalent temperature chart, Bull. Amer. Meteor. Soc., 86(10), 1453-1458.

Park, C.-Y., Kim, S.-T., Choi, Y.-E., and Kim, N.-J., 2014, Examination of tourism climatic conditions for Chiaksan National Park analyzing tourism climate index, J. Korean Geographical Soc., 49(5), 779-793 (in Korean).

Perch-Nielsen, S. L., Amelung, B., and Knutti, R., 2010, Future climate resources for tourism in Europe based on the daily Tourism Climatic Index, Climatic Change, 103(3-4), 363-381.

Scott, D., Gössling, S., and de Freitas, C. R., 2008, Preferred climates for tourism: case studies from Canada, New Zealand and Sweden, Climate Research, 38(1), 61-73.

Scott, D., McBoyle, G., and Schwartzentruber, M., 2004, Climate change and the distribution of climatic resources for tourism in North America, Climate Research, 27(2), 105-117.

Steadman, R. G., 1984, A universal scale of apparent temperature, J. Clim. Appl. Meteorol., 23(12), 1674-1687.

UNWTO and UNEP, 2008, Climate Change and Tourism: Responding to Global Challenges, UNWTO, Madrid.

책임 편집: 이의한 영문 교열: 이은걸 